\title{
Are Carbon Prices Redundant in the 2030 EU Climate and Energy Policy Package?
}

\author{
Finn Roar Aune and Rolf Golombek ${ }^{a} *$
}

\begin{abstract}
In 2018, an agreement between the key EU institutions - the Commission, the European Parliament, and the European Council—was reached after a long-lasting discourse over the 2030 EU climate and energy policy package. This paper offers a comprehensive assessment of the EU package, with its three main targets: lower greenhouse gas emissions, higher renewable share in final energy consumption, and improved energy efficiency. We find that the renewable and energy efficiency targets have been set so high that the derived emissions reduction (50 percent) exceeds the EU climate target (40 percent). Hence, there is no need for an EU climate policy, for example, to use carbon prices to reach the EU climate goals. It is, however, not cost-efficient to achieve the climate target by imposing the three EU targets. We demonstrate that a cost-efficient policy that obtains a 50 percent GHG emissions reduction would increase annual welfare (relative to the Reference scenario) by an amount corresponding to 0.6 percent of GDP in Europe.
\end{abstract}

Keywords: Climate policy, Renewables, Energy efficiency, Energy modeling, EU 2030

https://doi.org/10.5547/01956574.42.3.faun

\section{INTRODUCTION}

In 2018, an agreement between the key EU institutions - the Commission, the European Parliament, and the European Council — was reached after a long-lasting discourse over the 2030 EU climate and energy policy package. While there had been disagreement over the types of energy targets and how ambitious the targets should be, the parties agreed to an EU-wide renewable share in final energy consumption of 32 percent (Eur-lex (2018a)), to improve EU energy efficiency by 32.5 percent (relative to 2005) (Eur-lex (2018b)), and also to reduce greenhouse gas (GHG) emissions by (at least) 40 percent (relative to 1990) (Europa (2019a)). The aim of this paper is to offer a comprehensive assessment of the approved EU 2030 climate and energy package. As there have been intense debates on which targets the EU should reach, we also analyze the 2030 outcome if, hypothetically, alternative energy policy targets had been agreed upon (or the EU energy targets are changed in the future).

The motivation of this paper is that the EU 2030 policy package is probably the single most important factor with respect to the development of the European energy markets and it also

a CREE - the Oslo Centre for Research on Environmentally friendly Energy, which was supported by the Research Council of Norway until the end of 2019.

* Corresponding author. E-mail: rolf.golombek@frisch.uio.no.

The Energy Journal, Vol. 42, No. 3. This is an open access article under the terms of the Creative Commons Attribution License (CC-BY), which permits use, distribution and reproduction in any medium, provided the original work is properly cited. All rights reserved. 
has powerful implications for policy design. The package is complex as it contains three types of targets: GHG emissions, renewables, and energy efficiency. Each target will contribute to decreased GHG emissions, although the partial effects of reaching each target differ: standard economic theory suggests that if a higher share of renewables in energy consumption is obtained through producing more renewable electricity, the price of electricity is pushed down. Then units such as fossil-fuel power plants with high operating costs will be phased out. With less fossil-based electricity, GHG emissions drop. ${ }^{1}$ Economic theory also suggests that improved energy efficiency tends to lower the demand for fossil energy. Therefore, the price of fossil energy declines and fossil fuel-based energy production is phased out.

While standard economic theory predicts the main effects of reaching each of the targets in the EU 2030 package, the net effects of reaching all targets, as well as the magnitude of the effects, cannot be predicted from theory; a numerical model is needed. In this study, we will use the numerical model LIBEMOD to find the equilibrium effects of the EU 2030 climate and energy package, see LIBEMOD (2015).

LIBEMOD is a multigood, multiperiod model covering the entire value chain in the energy markets in 30 European countries from investment, extraction, and production via trade to consumption. In LIBEMOD, emissions reductions in the electricity generation sector are accomplished through a different mix and scale of electricity technologies; a higher price of emissions triggers less investment in, and production of, fossil fuel-based electricity. In the end-user sectors, emissions reductions require higher end-user prices. LIBEMOD determines all energy prices and quantities in the European energy markets. Because renewable electricity plays a critical role in reaching the 2030 EU targets, investment in hydro, bio, wind, and solar power is endogenous in LIBEMOD. The model finds the combination of policy instruments that is consistent with reaching all policy goals.

This paper makes three contributions to the literature. Whereas the 2030 EU climate and energy policy package was analyzed in a commissioned work by the EU Commission, see PRIMES (2019), the present paper is the first "external" study of the 2030 package. Our first contribution is to characterize the outcome when all EU climate and energy targets are required to be met. We find that the targets for renewables and improved energy efficiency have been set so high that the implied GHG emissions reduction is 50 percent, which is higher than the agreed-upon 40 percent target. This result is in line with PRIMES (2019), which found that the 2030 package will lower GHG emissions by 46 percent. We compare our results to PRIMES (2019) as well as to other studies that have imposed some of the targets in the 2030 package.

The EU climate target of a 40 percent emissions reduction by 2030 should, according to EU decisions, be reached by cutting emissions in the ETS sectors (electricity generation, carbon-intensive manufacturing firms, petroleum extraction and most of aviation) by 43 percent relative to 2005, whereas emissions in the remaining sectors (non-ETS) should be reduced by 30 percent relative to 2005 . We find that by achieving the renewable and energy efficiency targets, both the ETS and non-ETS emissions targets are met (see Section 5). Hence, there is no need for a climate policy. However, while an efficient emissions reduction is characterized by equal marginal cost of emissions reduction in the ETS and non-ETS sectors, there is no reason to believe that cost efficiency will be reached when the emissions reduction is obtained through achieving the renewable and energy efficiency targets. In fact, we demonstrate that if a 50 percent GHG emissions reduction is reached cost-efficiently, then annual welfare increases (relative to the Reference scenario above) by an amount corresponding to 0.6 percent of GDP in Europe (see Section 6.3).

1. For econometric assessments of the emissions offset by renewable energy, see Cullen (2013) for Texas, Callaway et al. (2018) for the US, and Abrell et al. (2019) for Germany and Spain. 
For years there has been a heated debate in the EU on whether there should be policy targets for renewables and improvement in energy efficiency, and if so, how ambitious these should be (see Section 3). Our second contribution is to examine how a renewable share in final energy consumption other than 32 percent, as well as an improvement in energy efficiency other than 32.5 percent, will affect emissions in the ETS and non-ETS sectors (see Section 6.1). We also show how the policy instruments imposed to reach the two energy policy targets need to be adjusted when the energy targets take alternative values. For example, we examine by how much the renewable share can be reduced below 32 percent (or the improvement in energy efficiency can be reduced below 32.5 percent) before either the ETS or the non-ETS emissions reduction target bites. We find that if the renewable share is 23 percent (and the improvement in energy efficiency is 32.5 percent), then ETS emissions are exactly 43 percent below their 2005 value. Hence, if the renewable share is below 23 percent (and the improvement in energy efficiency is 32.5 percent), it is necessary to have a positive price on $\mathrm{CO}_{2}$ emissions in the ETS sector in 2030 in order to meet the requirement that ETS emissions should be 43 percent lower than in 2005.

Our third contribution is to the energy modeling literature. Here, our main contribution is to offer a framework for endogenizing investment in intermittent power (wind and solar power) and to present a calibration strategy that quantifies structural wind and solar parameters. We derive first-order conditions for investment in and production of intermittent power by solving an optimization problem with the same structure as for any other electricity technology. However, we take into account that production sites differ with respect to wind conditions and solar irradiance. This is captured by a structural relationship between a measure for generated wind (or solar) power in a country and installed wind (or solar) capacity. We calibrate these relationships by utilizing detailed, spatial information about hourly wind speed, solar irradiance, reflection, and air temperature. For calibration, we have to make assumptions about the share of grid cells that will be available for the development of wind and solar power. We can, however, easily test how alternative land-availability assumptions affect energy markets (Section 6.2).

The remainder of the paper is structured as follows. Section 2 provides a short review of two strands of the literature that are related to the present paper, namely achieving climate and energy targets, and efficiency of electricity markets. In Section 3, we give a summary of the debate that culminated in 2018 when the key EU institutions agreed upon the 2030 policy package. The numerical model LIBEMOD, which is used to analyze the 2030 climate and energy package, is presented in Section 4, whereas the resulting 2030 equilibrium is described in Section 5. In Section 6, we provide two types of robustness analysis: alternative policy targets and alternative parameter values. Section 7 concludes.

\section{RELATED LITERATURE}

Our paper is linked to two strands of the energy economics literature: policy instruments used to reach climate and energy targets, and the efficiency of electricity markets with a high share of intermittent supply.

\subsection{Climate and energy policy targets}

Our paper contributes to the empirical literature on how climate and energy targets have impacted European energy markets. ${ }^{2}$ This literature covers the following: (i) the 2020 EU climate

2. There is a comprehensive literature on how to reach international climate policy targets, in which numerous numerical 
and energy package with its three 20 percent targets (GHG emissions, renewables, and energy efficiency); (ii) the 2030 EU climate and energy targets; and (iii) the European energy market in 2050, in particular, how the way the EU intends to reduce GHG emissions by at least 80 percent by 2050 affects the energy sector.

EU 2020

Böhringer et al. (2009) provide an economic impact assessment of the $2020 \mathrm{EU}$ goal to reduce emissions by at least 20 percent relative to 1990. To identify the impacts of the EU climate policy, they use a computable general equilibrium model of international trade and energy and simulate alternative scenarios. Boeters and Koornneef (2011) examine the cost of imposing a 20 percent renewable target in addition to the climate target of a 20 percent emissions reduction by 2020 . Using the computable general equilibrium model WorldScan, they find that the renewable target increases costs by 6 percent; however, this estimate is sensitive to a number of key assumptions. Landis and Heindl (2019) study distributional effects of the 2020 EU climate and energy policy. Using the computable general equilibrium model PACE, they explore how higher renewable shares, which push down the ETS price, generate distributional effects within and between EU member countries. Their results indicate that the effort of the EU to redistribute policy costs through permit allocation has been successful.

EU 2030

PRIMES (2019), a study commissioned by the EU Commission, examines the 2030 climate and energy package, as we do. They find that GHG emissions will be reduced by 46 percent by 2030 (relative to 1990), which is rather similar to our result of a 50 percent emissions reduction. Sandbag (2019) examines emissions reduction in the EU by 2030 taking all policies already in place into account. These include the clean energy package, the mobility packages, and announced coal phaseouts. The implied GHG emissions reduction is estimated to 50 percent. ECF (2011) investigates changes in the European power market by 2030 that are considered to be consistent with the 2050 target of reducing GHG emissions by 80-95 percent relative to 1990, see European Commission (2011). Babonneau et al. (2018) use the computable general equilibrium model GEMINI-E3 to examine how the EU effort sharing agreement, which sets emissions requirements for 2030 for the non-ETS sectors, generates costs on member states. Finally, Panos and Densing (2020) examine how the European electricity market is affected by the clean energy for all Europeans package, ${ }^{3}$ which implements the nationally determined contributions of the EU member states as part of the Paris Agreement. They find that the price of electricity will increase substantially from the current level, mainly because of increased fuel and $\mathrm{CO}_{2}$ prices, although batteries will lower price peaks.

EU 2050

Egerer et al. (2016) apply a spatial, bottom-up, techno-economic electricity sector model to study the need for expansion of the electricity transmission capacity by 2050 under alternative assumptions about EU 2050 emissions targets. For most 2050 climate targets being investigated,

models have been developed and applied. Results from a large share of these studies have been included in various IPCC reports, in particular, the most recent report on global warming of $1.5^{\circ} \mathrm{C}$, see IPCC (2019).

3. Based on Commission proposals published in November 2016, the clean energy for all Europeans package, see Europa (2019b), consists of eight legislative acts. After political agreement by the Council and the European Parliament in 2018 and early 2019, enabling all of the new rules to be in force by mid-2019, EU countries have 1-2 years to transpose the new directives into national law. 
upgrading of domestic electricity networks is required, whereas only modest investment in interconnectors is needed. Furthermore, Abrell and Weigt (2016) examine required network investment by 2050, but in contrast to Egerer et al. (2016), they also consider natural gas; through liberalization of the European energy markets, there is increased interfuel competition between these two energy carriers. Thus, network investments should be studied jointly.

Jägemann et al. (2013) analyze alternative pathways for the European electricity generation sector toward 2050 under the assumption that the GHG emission target should be a reduction of at least 80 percent. This requires an almost complete decarbonization of the electricity sector. Applying a linear dynamic electricity system optimization model, their study shows that if there is also a renewable target in addition to the GHG target, or if there are restrictions on investment in nuclear power or power stations with carbon capture and storage (CCS), the costs of obtaining the GHG target increase significantly.

This short review reveals that, to our knowledge, there is only one previous study of the 2030 EU climate and energy policy package. In fact, most studies focus on either 2020 or 2050, or on the emissions reduction in the electricity sector by 2030. In Section 5.2, we discuss the 2030 studies referred to above and compare these with our results.

\subsection{Competition and efficiency}

Our paper is also related to the extensive literature on market design of an electricity sector with a high share of renewables. Here, contributions cover theoretical considerations, policy evaluations, as well as econometric ex post assessments.

\section{Theoretical considerations}

With a high share of intermittent power, the functioning of the electricity industry changes and therefore regulation should be redesigned. For a discussion of appropriate market design, see, for example, Perez-Arriaga and Batlle (2012), Egerer et al. (2015), Neuhoff et al. (2016), Pollitt and Anaya (2016), De Vries and Verzijlbergh (2018), and Newbery et al. (2018). Egerer et al. (2015) describe conditions under which incentive regulation performs better than cost-based regulation. Burger et al. (2019a; 2019b) discuss regulatory design of an electricity retail sector with substantial distributed electricity production, and Wolak (2019) discusses efficient pricing in the entire electricity value chain that will sustain a low-carbon electricity sector. Finally, Ambec and Crampes (2019) demonstrate that in a model with two sources of energy - polluting thermal power and emission-free intermittent supply - it is necessary with a price cap and volume-limited capacity payments to implement the first-best social outcome if a carbon tax cannot be imposed.

Part of the literature focuses on instrument choice to promote renewables, and the related question of how to avoid underinvestment in renewables. Newbery (2012) discusses what type of feed-in tariffs government should offer low-carbon technologies in order to encourage investment and reduce risk. Whereas the UK government had a preference for a contract for difference for all generation, Newbery (2012) supports fixed feed-in tariffs. Green and Yatchew (2012) point out that feed-in tariffs have been effective in supporting a rapid growth in intermittent capacity, mainly because risk has been shifted away from suppliers and tariffs have been generous. They advise policy makers to design instruments that provide better locational and temporal price signals.

Newbery (2018) argues that well-designed electricity liberalization has delivered efficiency gains, but investment incentives in energy-only markets have been undermined because of the political risk of decarbonization. Drawing on principles from economic theory, the paper pro- 
poses guidelines to ensure optimal investment. Léautier (2016) also analyzes various corrective mechanisms that have been proposed to alleviate underinvestment in the electricity generation sector. The paper demonstrates that markets for capacity certificates restore optimal investment if and only if producers cannot sell more certificates than their installed capacity. Furthermore, financial reliability options are effective at curbing market power, although they do not fully restore correct investment incentives.

\section{Empirical assessments}

Böhringer et al. (2017) examine the Energiewende, the transformation of the German electricity system from fossil based to mainly renewable electricity through massive subsidies to zero-emission technologies. Using both a computable general equilibrium model and microsimulations, Böhringer et al. (2017) identify the economic impact of the Energiewende. While the results indicate that low-income households bear a high share of the cost, this harmful distributional effect can be alleviated by imposing alternative subsidy arrangements. Andor et al. (2017) also analyze the Energiewende. Drawing on two stated-preference surveys, they conclude that there is a strong contrast between households' general acceptance of supporting renewable technologies and their willingness to pay for renewable electricity production. Finally, Marcantonini and Ellerman (2015) analyze the derived costs of promoting wind and solar power in the Energiewende.

Grubb and Newbery (2018) assess the UK 2013 market reform, which aimed at securing funding for investment in low-carbon technologies and at the same time ensure energy security. The reform was successful to the extent that the market share of coal power dropped substantially because of a carbon price floor, whereas the opposite was the case for renewable electricity. However, the reform revealed that to achieve a low-emission society, transmission pricing and locational signals are decisive.

Keppler et al. (2016) examine how increased intermittent supply impacts price variation across countries. Using a sample of hourly day-ahead prices in Germany and France from November 2009 to June 2013, they find that when transmission capacity between the two countries is limited, more intermittent supply in Germany leads to increased price spreads between the two countries.

Haar and Haar (2017) study support schemes for renewable electricity in some large EU economies. Using data for 2009-2013, they argue that the schemes that were used provided sufficient incentives to reach the target capacities, but at an unnecessarily high cost. This justifies the question of whether almost mature renewable electricity technologies, such as onshore wind, should continue to receive financial support; see Held et al. (2019) for a discussion.

Turning to the EU, Duso et al. (2019) examine the impact of competition policy on the effectiveness of the European energy markets. They find that EU merger policy had a positive significant effect on investment and productivity in low-regulated sectors. Gugler et al. (2018) investigate the degree of market integration in the European electricity market by examining the variability of day-ahead spot prices. Using co-integration analysis, they conclude that market integration increased between 2010 and 2012, but then declined until 2015, despite market coupling being introduced.

In the LIBEMOD model, the EU has access to a set of instruments that ensures that all targets are reached. For example, we use an EU-wide subsidy to achieve the EU-wide target for renewables. This will ensure that the policy target is reached efficiently; the same is the case for each of the other policy goals of the 2030 EU policy package. In Section 6, we discuss economic efficiency and policy targets. 


\section{CLIMATE, RENEWABLES, AND ENERGY EFFICIENCY TARGETS IN THE EU}

The primary aim of this paper is to investigate how the 2030 EU climate and energy policy targets may impact energy markets in 2030. Prior to adopting the 2030 climate and energy policy package in 2018, there had been intense debates in the EU on whether it was sufficient to impose climate and renewable targets, or whether energy efficiency targets should also be imposed. The position of countries on this question reflected their experience with implementing the 2020 policy package with its 20 percent targets on GHG emissions, renewables, and energy efficiency. According to Skjærseth et al. (2016), countries can be divided into three groups.

First, there was a group of countries that were not pleased with the 2020 package. This group includes countries in Eastern and Central Europe that use coal as their major energy source. The group was headed by Poland, which discovered that the 2020 package was inappropriate given the nature of its energy sector and climate policy. In particular, a more ambitious renewables policy had reduced Poland's energy imports only marginally. These countries opposed new GHG targets and also policies directed at renewable energy and energy efficiency.

Second, there was a group of countries that had a mixed experience with the 2020 package. This group includes the major energy-exporting countries Norway and the Netherlands, and also the UK. These countries supported a more ambitious GHG target but did not want renewable and energy efficiency targets; energy-import dependency is not a concern for these countries.

Third, there was another group of countries that had a mainly positive experience with the 2020 package. This group includes the key EU member states Germany, France, and Italy. Germany, which had achieved diffusion in green technologies and growth in green employment, wanted more ambitious targets for renewable energy and improved energy efficiency. This position was shared by six other EU member states.

Whereas the European Parliament supported three binding targets - a 40 percent GHG emissions reduction, a 30 percent renewable share in final energy consumption, and a 40 percent higher energy efficiency - the Commission was split. The Climate Commissioner wanted all three targets, as opposed to the Energy Commissioner and the Industry Commissioner. They opposed a higher renewable energy target, fearing that a new renewable-energy goal could push up energy prices, thereby threatening the competitiveness of key EU industries.

In January 2014, the Commission announced its compromise proposal: a 40 percent GHG emissions reduction and an EU-wide renewable target of 27 percent. Although no new target for energy efficiency was proposed, the Commission stated that 25 percent energy savings would be required in order to reach the GHG target.

The response to the proposal of the Commission was split. A "Green Growth Group" of 14 countries endorsed the key elements of the proposal. In contrast, a group led by Poland, with support from several Eastern and Central European countries, demanded full national sovereignty over the energy mix as well as the protection of coal, more EU subsidies to modernize the energy system, and more costs borne by rich EU countries.

The negotiations over the 2030 climate and energy policies culminated temporarily in the fall of 2014 with the European Council's adoption of a 40 percent GHG emissions reduction, a renewable share of 27 percent, and an indicative target of a 27 percent increase in energy efficiency. This was a compromise to satisfy the main veto players. As a carrot for Eastern and Central European countries, burden sharing for non-ETS emissions reduction would be based on GDP per capita, which had also been the case for the 2020 package. Other countries, as well as EU institutions, had mixed feelings about the adopted policy of the European Council. 
In the summer of 2018, a final agreement was reached between the Commission, the European Parliament, and the European Council. The parties agreed on an EU-wide renewable share of 32 percent, and also to introduce a binding EU-wide improvement in energy efficiency of 32.5 percent. The fact that these two targets are EU-wide, not national targets, may have made it easier for the parties to reach an agreement. The EU intends to use its governance system to ensure that these targets will be met.

Because it has been widely debated how ambitious the renewable policy target and the imposed improvement in energy efficiency should be, and because the climate and energy policy of the EU will be revised in 2023, this paper discusses, using the numeric energy model LIBEMOD, how alternative values of these two targets will impact the 2030 equilibrium (see Section 6).

\section{LIBEMOD}

In this section, we describe the numerical multimarket, multigood equilibrium model LIBEMOD, which is applied to examine how EU climate and energy targets for 2030 impact the energy markets. LIBEMOD allows for a detailed study of the energy markets in Europe, taking into account factors such as fossil fuel extraction, interfuel competition, technological differences in electricity supply, key characteristics of renewable electricity technologies, transport of energy through gas pipes/electricity lines, and investment in the energy industry. The model determines simultaneously all energy prices and all energy quantities invested, extracted, produced, traded, and consumed in each of 30 European countries - henceforth referred to as EU-30. ${ }^{4}$ The model also determines all energy prices and quantities traded in world markets, as well as emissions of $\mathrm{CO}_{2}$ by country and sector (Figure 1).

Figure 1: The LIBEMOD model

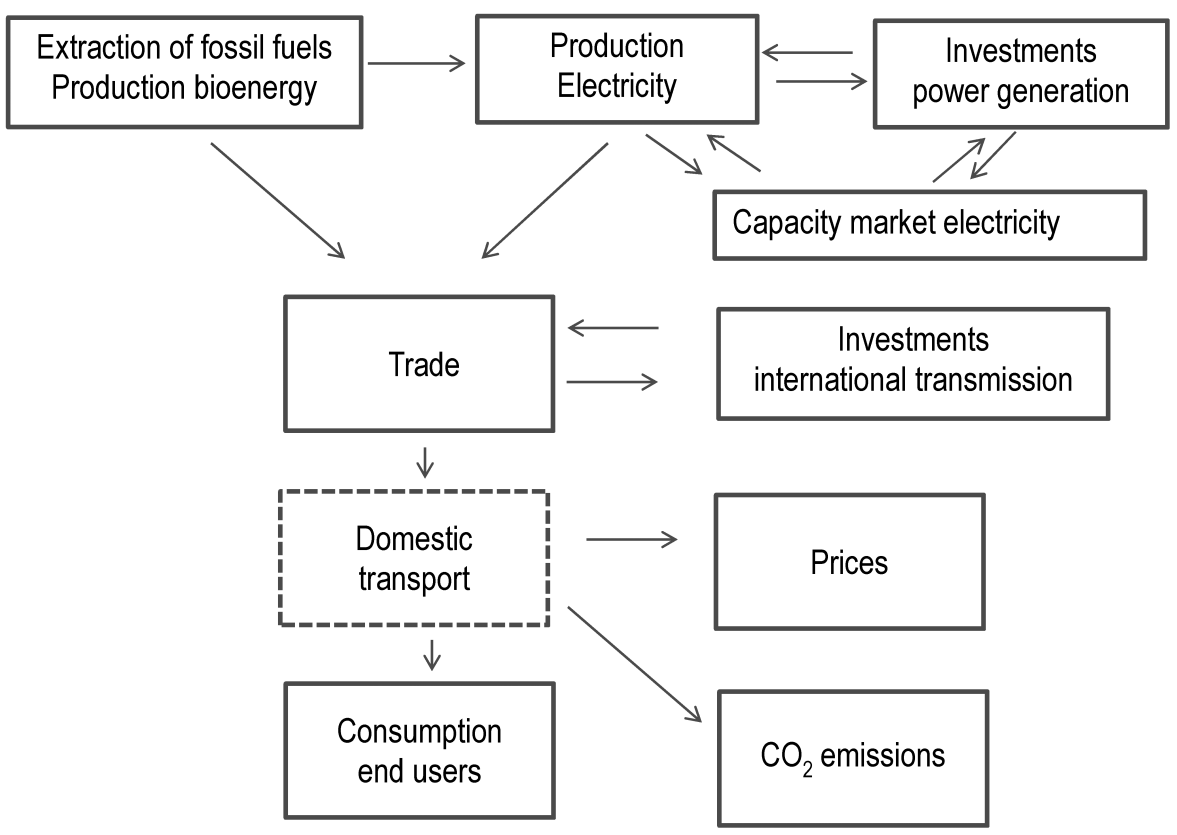

4. See Table B.1 in Appendix B for a list of these 30 countries. 


\subsection{General description}

The core of LIBEMOD is a set of competitive markets for eight energy goods: natural gas, oil, steam coal, coking coal, lignite, biomass, biofuel, and electricity. ${ }^{5}$ Energy goods are extracted/ produced, traded, and consumed in each country in EU-30.

Extraction of all fossil fuels and production of biomass are modeled by standard (nonlinear) supply functions, whereas electricity is produced using a number of technologies (see discussion below). Natural gas, biomass, and electricity are traded in competitive European markets. Trade in natural gas requires gas pipelines that connect pairs of countries. Similarly, trade in electricity requires electricity transmission lines that connect pairs of countries. The capacity of transmission gas pipes and electricity lines can be extended through investment; see Appendix A, Part I, for details.

In LIBEMOD, there are competitive world markets for coking coal, steam coal, oil, and biofuel, and competitive domestic markets for lignite. While fuels are traded in annual markets, there are seasonal (summer vs. winter) and time-of-day markets for electricity.

In each country in EU-30 (henceforth referred to as a model country), there is demand for all types of energy from four groups of end users: the household sector, the services and public sector, the industry sector, and the transport sector (which covers transport demand in the other three end-user sectors). Demand from each end-user group (in each model country) is derived from a nested multigood, multiperiod constant elasticity of substitution (CES) utility function, making LIBEMOD a truly nonlinear model. In addition, there is intermediate demand for fuels from fuel-based electricity producers; gas-fired power stations demand natural gas, biopower stations demand biomass, etc. Intermediate demand for fuels from power plants is derived from maximizing profits subject to a number of restrictions. In LIBEMOD, these are expressed as standard first-order conditions.

In each model country, there is domestic transportation and distribution of energy with associated costs. The end-user price of an energy good is thus the sum of (i) the producer price of this good, (ii) costs of domestic transportation and distribution of this energy good (which differ between countries, end-user groups, and energy goods), (iii) end-user taxes, and (iv) losses in domestic transportation and distribution.

Furthermore, in each model country the national regulator has to ensure that the domestic electricity market does not break down if there is an unexpected increase in net demand because of, for example, technical operational problems of power plants, lower supply from intermittent sources (wind power and solar), or higher demand. To avoid a blackout, the regulator acquires idle maintained capacity in the national capacity market; see Appendix A, Part II, for details.

In LIBEMOD, there is a competitive equilibrium for each good. This is the case for (i) all goods traded in a model country, (ii) all energy goods traded in world markets (oil, steam coal, coking coal, and biofuel), and (iii) international transport services for natural gas and electricity be-

5. The European Commission has for more than 25 years aimed at establishing efficient European energy markets. We assume that this goal is reached by 2030. There are several indications that the European markets have become substantially more competitive, see, for example, European Commission (2019). This report finds that wholesale energy prices have fallen in recent years because of increasing competition in wholesale markets from greater amounts of renewable energy, improved interconnections, and a more integrated internal electricity market. Furthermore, for the first time since 2008, household electricity prices decreased. Pollitt (2019) examines the Commission's own work on evaluating the benefits of the single electricity market and also considers the evidence of the impact on prices, security of supply, the environment, and innovation. Pollitt concludes that the institutional changes are extensive and there has been significant market harmonization and integration. For a similar study on the European natural gas market, see Chyong (2019), which argues that arbitrage possibilities are now fully exploited. 
tween model countries. The price of each transport service consists of a unit cost and an endogenous capacity term; the latter ensures that demand for transport does not exceed the capacity of the gas pipe/electricity line. International transport capacities consist of two terms: predetermined capacities (according to observed capacities in the data year of the model) and investment in capacities; the latter is undertaken if it is profitable.

\subsection{Supply of electricity}

In LIBEMOD, supply of electricity is the most detailed model block. In each model country, there are 13 preexisting (“old") electricity technologies: steam coal power, lignite power, gas power, oil power, biopower, reservoir hydropower, run-of-river hydropower, pumped storage hydropower, nuclear power, waste power, wind power, solar power, and a composite technology referred to as other renewables (geothermal power, wave power, and tide power). Moreover, there are four new fossil fuel-based technologies: new steam coal power, new steam coal power with CCS, new gas power, and new gas power with CCS. ${ }^{6,7,8}$ Furthermore, there are six new renewable technologies: new reservoir hydropower, new run-of-river hydropower, new pumped storage hydropower, new biopower, new wind power, and new solar power.

In general, for each old fuel-based technology and each model country, efficiency varies across electricity plants. However, instead of specifying heterogeneous plants for each old technology, we model the supply of electricity from each old fuel-based technology as if there were one single plant with decreasing efficiency; this implies increasing marginal costs in each model country. For each type of new fuel-based technology, we assume, however, that all plants have the same efficiency. Whereas capacities for old technologies are exogenous (in each model country), for new plants, capacity, that is, investment, is determined by the model according to profitability.

There are six types of costs involved in electricity supply from the combustion of fuels. First, there are nonfuel monetary costs directly related to the production of electricity in period $t, y_{t}$, where $t \in T$. Second, there are fuel costs. Third, production of electricity requires that capacity is maintained: in addition to choosing an electricity output level (TWh), the producer chooses the level of power capacity $(\mathrm{GW})$ that is maintained, $K^{P M}$, thereby incurring a unit maintenance $\operatorname{cost} c^{M}$ per power unit. Fourth, if producers choose to produce more electricity in one period than in the previous period in the same season, they will incur start-up costs. In LIBEMOD, these costs are partly expressed as an extra fuel requirement, but also as a monetary cost per unit of started power capacity.

For investments in new power capacity, $K^{i n v}$, there are annualized capital $\operatorname{costs} c^{i n v}$ related to the investment. Finally, for new plants, there are also costs related to connecting to the grid; these reflect either that the site of the plant is not located at the grid or that connecting a new plant to the grid requires upgrading of the grid and these costs are borne by the plant. The cost of grid connection $(g c), c^{g c}\left(K^{i n v}\right) K^{i n v}$, is assumed to be increasing and convex.

6. In addition, old coal power plants and old gas power plants can be retrofitted with CCS.

7. In the global electricity generation sector, there were only two CCS power stations in operation by the end of 2017; both are coal power plants with retrofitted CCS. Their aggregated annual capture capacity was $2.4 \mathrm{Mt} \mathrm{CO}_{2}$. This number can be compared with the capture capacity in the Sustainable Development Scenario in IEA (2018); this global scenario has been constructed to provide a cost-efficient path that is consistent with the Paris Agreement and sustainable water use. Annual capture in the electricity sector in the Sustainable Development Scenario is $350 \mathrm{Mt} \mathrm{CO}_{2}$ in 2030 and $1500 \mathrm{Mt} \mathrm{CO}_{2}$ in 2040. Note that worldwide, there are currently seven CCS power station projects under early development. Their aggregated annual capture capacity is "only" $10.5 \mathrm{Mt} \mathrm{CO}_{2}$.

8. Because of high costs, there is no investment in oil power in the LIBEMOD model runs, whereas investment and disinvestment in nuclear are exogenous because a number of noneconomic factors are also of importance when deciding future nuclear capacity. For all EU-30 countries, nuclear capacities in 2030 are taken from the World Nuclear Association (2019). 
Each fossil fuel-based plant maximizes profits subject to a number of technology constraints: (i) maintained power capacity should not exceed installed power capacity; (ii) instantaneous production of electricity should not exceed the net power capacity; and (iii) during the year, there should be some downtime for technical maintenance.

Biopower is modeled in exactly the same way as electricity supply from fossil fuel-based technologies. The only difference is that biopower uses biomass as an input. Like fossil fuels, biomass is supplied competitively and there is one thermal efficiency rate of new biopower plants. ${ }^{9}$

In LIBEMOD, there are three types of hydroelectricity technologies: reservoir hydro, runof-river hydro, and pumped storage hydro. Relative to the modeling of electricity supply from fuel-based technologies, reservoir hydro, which has a reservoir to store water, has two additional technology constraints. First, the reservoir filling at the end of a season cannot exceed the reservoir capacity. Second, total use of water should not exceed total supply of water, that is, total production of reservoir hydropower in a season plus the amount of water in the reservoir at the end of this season should not exceed the amount of water in the reservoir at the end of the previous season plus the seasonal inflow of water.

For the run-of-river hydropower technology, there is, as per definition, no reservoir. In each time period, production of electricity cannot exceed the inflow of water. The run-of-river hydropower technology has, like reservoir hydro, increasing marginal cost of investment, which reflects the heterogeneity of sites. The pumped storage hydropower technology is characterized by buying electricity in one period (typically during the night) and using that energy to pump water up to the reservoir to produce electricity in a different time period (typically during the day when the price is high). As demonstrated by Aune et al. (2008), the optimization problem of this technology is similar to that for fossil fuel-based technologies, except that the pumped storage producer uses electricity (not a fossil fuel) as an input. ${ }^{10}$

We now turn to a detailed discussion of the modeling of wind power and solar power.

\subsubsection{New wind power}

Wind sites differ with respect to wind speed. By using a power curve, that is, the relationship between wind speed and wind energy, $1 \mathrm{MW}$ capacity of wind power is transformed into generated wind energy at each point in time. If the wind speed is below a threshold value, say, 3.5 $\mathrm{m} / \mathrm{s}$, no wind energy is generated. In contrast, $1 \mathrm{MW}$ capacity generates $1 \mathrm{MWh}$ energy under ideal wind conditions, that is, the wind speed exceeds another threshold value, say, $15 \mathrm{~m} / \mathrm{s}$, at each point in time during an hour. For a given power curve and detailed information on wind speed, total generated wind energy can be calculated over a year at a site with $1 \mathrm{MW}$ installed capacity. Next, one can

9. In LIBEMOD there are two types of bioenergy: biomass (used in the electricity generation sector) and biofuel (used in the transport sector). Whereas production of biomass requires land, we do not impose a biomass land-use restriction in LIBEMOD. The reason is that the equilibrium quantities of biomass mainly consist of waste and by-products from agriculture and industry, that is, biomass products do not require separate land. For biofuels, the alternative value of land may be substantial; see, for example, Searchinger et al. (2008). Because equilibrium consumption of biofuel is moderate in LIBEMOD, there is no need to introduce restrictions on land use for biofuel production.

10. We use an extended and updated version of LIBEMOD that builds on the earlier version that was documented in Aune et al. (2008). In the new version of the model, more countries have been added (mainly Eastern European countries); the enduser sectors have been refined (services and the public sector have been separated from the household segment); the modeling of wind power has been changed and more renewable technologies have been included (run-of-river hydro and solar power); the modeling of natural gas has been refined (LNG has been included); bioenergy has been split into biomass and biofuel; all data have been updated (the data year has been changed from 2000 to 2009); and the complete model has been recalibrated (see LIBEMOD 2015). 
calculate the number of hours with ideal wind conditions that is required to generate the observed annual wind power production. We refer to this number as the full-load wind hours.

We assume that wind power producers maximize profits. Hence, the site with the highest full-load wind hours is developed first, then the site with the second highest full-load wind hours is developed, and so on until the marginal site is developed; here profit is zero. In general, the more sites that are developed, the lower is the average full-load wind hours. This is formalized by $f\left(K^{P M}\right), f^{\prime}<0$, where $K^{P M}$ denotes maintained capacity; capacity has to be maintained in order to be used for electricity production; see discussion in Section 4.2. By multiplying the average fullload wind hours per year, $f\left(K^{P M}\right)$, by how much wind power can be produced at each point in time, $K^{P M}$, a measure of annual production of wind power is obtained, $f\left(K^{P M}\right) K^{P M}$.

There are technical constraints also for new wind power. First, maintained power capacity should be less than or equal to installed power capacity, which for a new power plant is equal to investment in electricity production capacity:

$$
K^{P M} \leq K^{i n v} \perp \lambda \geq 0
$$

where $\lambda$ is the shadow price of installed power capacity.

Second, let $\psi_{t}^{w}$ be the share in period $t$ of the annual full-load wind hours. This means that production of wind power in period $t$ is $\psi_{t}^{w} f\left(K^{P M}\right) K^{P M}$. Hence, there is an upper limit on the production of electricity in this period:

$$
y_{t} \leq \psi_{t}^{w} f\left(K^{P M}\right) K^{P M} \perp \mu_{t} \geq 0
$$

where $\mu_{t}$ is the shadow price of the periodic electricity production capacity.

Similar to fuel-based technologies, wind power has a constant unit maintenance cost, $c^{M}$. However, there is of course no fuel cost and there are no start-up costs for a wind power plant. Therefore, the Lagrangian of the optimizing problem of new wind power is:

$$
\begin{gathered}
\mathcal{L}=\sum_{t \in T} p_{t} y_{t}-c^{M} K^{P M}-c^{i n v} K^{i n v}-c^{g c}\left(K^{i n v}\right) K^{i n v} \\
-\lambda\left\{K^{P M}-K^{i n v}\right\}-\sum_{t \in T} \mu_{t}\left\{y_{t}-\psi_{t}^{w} f\left(K^{P M}\right) K^{P M}\right\} .
\end{gathered}
$$

Here, $p_{t}$ is the price of electricity in time period $t$.

The first-order condition for the supply of electricity in each period $\left(y_{t}\right)$ is: ${ }^{11}$

$$
p_{t} \leq \mu_{t} \perp y_{t} \geq 0
$$

This is a standard first-order condition, simply stating that an interior solution, that is, $y_{t}>0$, requires that the price of electricity, $p_{t}$, should be equal to the shadow price of periodic electricity production capacity, $\mu_{t}$.

The first-order condition for maintained capacity $\left(K^{P M}\right)$ is:

$$
\left(\sum_{t \in T} \mu_{t} \psi_{t}^{w}\right)\left(f\left(K^{P M}\right)+f^{\prime}\left(K^{P M}\right) K^{P M}\right) \leq c^{M}+\lambda \perp K^{P M} \geq 0
$$

11. In LIBEMOD, investment, maintenance of the capacity, and production of electricity follow from the solution of maximizing profits subject to a number of constraints. The derived Kuhn-Tucker first-order conditions, which allow corner solutions, are used to find the equilibrium. Because of corner solutions (i.e., zero equilibrium quantity), it is more convenient to use the Kuhn-Tucker first-order conditions than to derive demand functions for inputs. 
This first-order condition states that the cost of increasing maintained capacity marginally - the sum of the maintenance cost $\left(c^{M}\right)$ and the shadow price of installed capacity $(\lambda)$ - should (in an interior solution) be equal to the value of increased annual production following from this policy. Increased maintained capacity raises potential periodic and annual electricity production. Therefore, the value of increased production is equal to the shadow price of periodic electricity production capacity $\left(\mu_{t}\right)$ weighted by the wind share in this period $\left(\psi_{t}^{w}\right)$ and summed over the year when the effect on annual production of wind power from increased maintained capacity $\left(f\left(K^{P M}\right)+f^{\prime}\left(K^{P M}\right) K^{P M}\right)$ is taken into account.

Finally, the first-order condition for investment is given by:

$$
\lambda \leq c^{i n v}+c^{g c}\left(K^{i n v}\right)+\frac{d c^{g c}\left(K^{i n v}\right)}{d K^{i n v}} K^{i n v} \perp K^{i n v} \geq 0 .
$$

This condition implies that if investment is positive, then total annualized investment cost, which is the cost of investment $\left(c^{i n v}\right)$ plus total marginal cost of connecting to the grid $\left(c^{g c}\left(K^{i n v}\right)+\frac{d c^{g c}\left(K^{i n v}\right)}{d K^{i n v}} K^{i n v}\right)$, should be equal to the shadow price of installed capacity $(\lambda)$, that is, the increase in operating surplus resulting from one extra unit of capacity. For calibration of (onshore) wind power parameters, see Appendix B, Part I.

\subsubsection{New solar power}

The main solar power technologies are centralized solar power (CSP) and photovoltaics (PV). We have chosen to model PV, which, based on available cost estimates (see, e.g., IEA (2016)), is the most promising technology.

Solar sites differ with respect to solar irradiance, and hence by the annual amount of electricity delivered to the grid per $m^{2}$ of solar park. We assume that solar power producers maximize profits. Hence, the site with the highest annual amount of electricity delivered to the grid per $\mathrm{m}^{2}$ is developed first, then the site with the second highest amount of electricity is developed, and so on. Hence, the more solar power that is developed, the lower is the average amount of generated electricity per $m^{2}$. This mechanism is captured by letting annual generated electricity delivered to the grid per $m^{2}$ be a downward-sloping function of maintained solar power capacity, $K^{P M}$, that is, by the amount of solar power that can be produced momentarily: $g\left(K^{P M}\right), g^{\prime}<0$. Let $\Omega$ be the amount of land used to produce solar power. Then $g\left(K^{P M}\right) \Omega$ measures annual solar power production delivered to the grid. Finally, let $\psi_{t}^{s}$ be the share of annual solar power production in period $t$. We then have a measure of solar production in this time period: $\psi_{t}^{s} \mathrm{~g}\left(K^{P M}\right) \Omega$.

A producer investing in solar power faces the same type of technical constraints as an agent investing in wind power. First, maintained power capacity should be less than or equal to installed power capacity, that is, $K^{P M} \leq K^{i n v}$. Second, period production of electricity is restricted: $y_{t}^{E} \leq \psi_{t}^{s} g\left(K^{P M}\right) \Omega$. Therefore, the Lagrangian of new solar power is similar to the Lagrangian of new wind power. Hence, the first-order conditions for solar power have similar interpretations as those for wind power. For calibration of the solar power parameters, see Appendix B, Part II.

\subsection{Parameterization}

Appendix B, Part III explains the main principle for calibrating the demand block of LIBEMOD, whereas LIBEMOD (2015) provides a full documentation of the LIBEMOD data and parameters. We mainly use these parameters, except for the electricity sector, where we use updated values for wind and solar power; see Appendix B, Parts I and II. Costs and efficiency of electricity 
plants coming online in 2030 are taken from IEA (2016); see Tables 1 and 2. In Table 1, we have gathered estimates of investment costs for a number of electricity technologies from five sources. As seen from Table 1, costs differ substantially across sources, which reflects different assumptions with respect to type of technology and installment year.

Table 1: Investment costs for power plants $(€ 2009 / \mathrm{kW})$

\begin{tabular}{lccccc}
\hline Technology & IEA & $\begin{array}{c}\text { IEA ETSAP } \\
(2010)\end{array}$ & $\begin{array}{c}\text { Schröder et al. } \\
(2013)\end{array}$ & $\begin{array}{c}\text { OECD } \\
(2010)\end{array}$ & $\begin{array}{c}\text { Mott MacDonald } \\
(2010)^{\mathrm{b}}\end{array}$ \\
\hline Natural gas & 819 & 800 & 800 & $775-1291$ & 806 \\
Coal & 1802 & 1600 & 1200 & $1534-1988$ & 2009 \\
Bio & 1884 & 2181 & - & $1934-5482$ & - \\
Solar (PV) & 704 & 2400 & 1560 & $2405-3802$ & - \\
Wind (onshore) & 1409 & - & 1300 & $1419-1742$ & 1707 \\
CCS natural gas & 2293 & & & & \\
CCS coal & 4095 & & & & \\
\hline
\end{tabular}

${ }^{a}$ The data from IEA (2016) are for the New Policy Scenario in 2030.

b The data from Mott MacDonald (2010) are for the " $\mathrm{n}^{\text {th }}$ of a kind plant" in their medium scenario.

Table 2: Efficiency (\%) and operation and maintenance $(O \& M)$ costs for new power plants in 2030 $(€ 2009 / \mathrm{kW})$ in LIBEMOD

\begin{tabular}{lcc}
\hline & Efficiency & O\&M costs $^{\mathrm{a}}$ \\
\hline Natural gas & 60 & 20 \\
Coal & 47 & 53 \\
Bio & 35 & 66 \\
Solar (PV) & & 10 \\
Wind (onshore) & & 36 \\
CCS natural gas & 53 & 74 \\
CCS coal & 39 & 147 \\
\hline
\end{tabular}

Source: IEA (2016).

${ }^{\text {a }}$ The O\&M costs have been decomposed into a fixed term (USD $\left./ \mathrm{kW}\right)$ and a variable term (USD/MWh) using information from OECD (2010) and IRENA (2012), and then transformed to $€ 2009$. For solar and wind power, we assume there is no variable cost term.

\section{REFERENCE SCENARIO}

\subsection{Equilibrium}

The EU has decided that GHG emissions should be reduced by 40 percent by 2030 relative to 1990. This policy distinguishes between the ETS sectors (electricity generation, carbon-intensive manufacturing firms, petroleum extraction and most of aviation) and the remaining sectors (nonETS). Whereas the ETS sectors have to reduce their GHG emissions by at least 43 percent relative to 2005 , the corresponding reduction for the non-ETS sectors is 30 percent.

In the Reference scenario, we therefore have one common EU-30 target for emissions in the ETS sectors (implemented by a common quota system) and one common EU-30 target for emissions in the non-ETS sectors (implemented by a common uniform carbon tax); see Table 3. ${ }^{12}$

12. In 2017, the EU decided on national non-ETS emissions targets. Our assumption of examining the non-ETS sectors as if there were an EU-wide emissions target is mainly a simplification, but it can partly be rationalized by the fact that the EU has allowed substantial flexibility mechanisms in non-ETS emissions reductions. 
Because LIBEMOD covers $\mathrm{CO}_{2}$ only (the most important GHG gas), we transform the GHG emissions targets to $\mathrm{CO}_{2}$ targets; see Appendix B, Part IV, for details.

In the Reference scenario, we also impose the agreed-upon target of an EU-wide renewable share in final energy consumption of 32 percent. ${ }^{13}$ In LIBEMOD, this policy goal is assumed to be reached through an EU-wide renewable subsidy offered to all producers of renewable electricity. Finally, we impose the agreed-upon target that EU energy efficiency should be 32.5 percent above the business-as-usual level in 2005. ${ }^{14}$ In our study, the energy efficiency target is reached through imposing an EU-wide tax on all types of energy (fuels and electricity) consumed by end users.

Table 3: Scenarios for 2030

\begin{tabular}{|c|c|}
\hline Reference & $\begin{array}{l}\text { At least } 40 \% \text { GHG emissions reductions in } 2030 \text { relative to } 1990 \text {. Separate emissions targets } \\
\text { for ETS and non-ETS sectors. A renewable share of } 32 \text { percent in final energy consumption. } \\
\text { Energy efficiency should be improved by } 32.5 \text { percent relative to business as usual. EU-wide } \\
\text { policy instruments only. }\end{array}$ \\
\hline No Targets & No policy targets. \\
\hline Climate Targets & $\begin{array}{l}40 \text { percent GHG emissions reductions in } 2030 \text { relative to } 1990 \text {. Separate emissions targets for } \\
\text { ETS and non-ETS sectors. }\end{array}$ \\
\hline $\begin{array}{l}\text { Climate and Renewable } \\
\text { Targets }\end{array}$ & $\begin{array}{l}40 \text { percent GHG emissions reductions in } 2030 \text { relative to } 1990 \text {. Separate emissions targets for } \\
\text { ETS and non-ETS sectors. A renewable share of } 32 \text { percent in final energy consumption. }\end{array}$ \\
\hline Cheap Solar & Same as Reference scenario, but all costs of solar power are reduced by one-third. \\
\hline More Land & $\begin{array}{l}\text { Same as Reference scenario, but in each grid cell twice as much land is available for both wind } \\
\text { and solar power park development than in the Reference scenario. }\end{array}$ \\
\hline Low Growth & Same as Reference scenario, but GDP growth rates are halved (2018-2030). \\
\hline Climate Efficiency & $\begin{array}{l}\text { Total GHG emissions equal to the equilibrium emissions level in the Reference scenario. One } \\
\text { climate target. }\end{array}$ \\
\hline
\end{tabular}

In equilibrium, the combination of a renewable share in final energy consumption of 32 percent and an improvement in energy efficiency of 32.5 percent lowers emissions by more than 43 percent in the ETS sectors (67 percent) and by more than 30 percent in the non-ETS sectors (35 percent). ${ }^{15}$ Therefore, the equilibrium emissions prices in the Reference scenario are zero in both the ETS and the non-ETS sectors; see second to last column in Table $4 .{ }^{16}$ In fact, we find that GHG

13. We define the share of renewables in final energy demand as: i) the sum of renewable electricity production and total end use of bioenergy (transformed to TWh) relative to ii) total consumption of electricity (less the electricity used in pumped storage hydro) and total consumption of primary energy among end users (transformed to TWh).

14. We use European Commission (2016) to quantify the energy efficiency target. Here, an improvement in energy efficiency of 30 percent by 2030 relative to 2005 is estimated to imply "a drop in final energy consumption of 17 percent compared with 2005." We can then calibrate what the final energy consumption in LIBEMOD should be in 2030 if energy efficiency is improved by 32.5 percent.

15. Whereas there is some flexibility of the emission caps of the ETS and non-ETS sectors, this will not have impact on our results. First, there is a flexibility mechanism between the ETS and non-ETS emissions targets. According to article 6 in European Parliament (2018), a maximum of 100 million EU ETS allowances can (by some countries) be transferred to the non-ETS sectors over the period 2021-2030. This will at most sharpen the ETS target by one percentage point. Second, over the period 2021-2030 the non-ETS cap can be increased by up to 280 million tons of $\mathrm{CO}_{2}$ equivalent because of removals from afforested land, deforested land, managed cropland and managed grassland, see Annex III in European Parliament (2018). Therefore, the non-ETS emissions reduction can be in the order of 28 percent (relative to 2005), which will of course not bite as we find that the renewable and energy efficiency targets will lower emissions by as much as 35 percent.

16. The result that it is not "necessary" to use instruments directly targeting GHG emissions, like a price on GHG emissions, to reach the climate target seems to be in line with the long-term vision of the Commission for a climate-neutral economy by 2050; see Europa (2018). Here, seven so-called strategic areas are highlighted: i) energy efficiency; ii) deployment 
emissions are 50 percent lower than in 1990, that is, the emissions reduction is 10 percentage points higher than the 40 percent target.

Table 4: Policy target sensitivity

\begin{tabular}{|c|c|c|c|c|c|}
\hline & $\begin{array}{l}\text { No } \\
\text { targets }\end{array}$ & $\begin{array}{c}\text { Climate Targets } \\
\text { (ETS and } \\
\text { non-ETS targets) }\end{array}$ & $\begin{array}{c}\text { Climate and } \\
\text { Renewable } \\
\text { Targets }\end{array}$ & $\begin{array}{l}\text { Climate, Renewable } \\
\text { and Energy } \\
\text { Efficiency Targets } \\
\text { (Reference scenario) }\end{array}$ & $\begin{array}{l}\text { Climate } \\
\text { Efficiency } \\
\text { (one climate } \\
\text { target) }\end{array}$ \\
\hline $\begin{array}{l}\text { GHG emissions in } 2030 \text { relative to } \\
1990\end{array}$ & $-2 \%$ & $-40 \%$ & $-40 \%$ & $-50 \%$ & $-50 \%$ \\
\hline Renewable share in 2030 & $11 \%$ & $24 \%$ & $32 \%$ & $32 \%$ & $28 \%$ \\
\hline $\begin{array}{l}\text { Improved energy efficiency in } 2030 \\
\text { relative to } 2005\end{array}$ & $3 \%$ & $17 \%$ & $11 \%$ & $32.5 \%$ & $24 \%$ \\
\hline ETS price $\left(€_{2009} / \mathrm{tCO}_{2}\right)$ & 0 & 62 & 14 & 0 & 322 \\
\hline Non-ETS price $\left(€_{2009} / \mathrm{tCO}_{2}\right)$ & 0 & 262 & 267 & 0 & 322 \\
\hline Renewable subsidy $\left(€_{2009} / \mathrm{MWh}\right)$ & 0 & 0 & 58 & 52 & 0 \\
\hline End-user tax $\left(€_{2009} /\right.$ toe $)$ & 0 & 0 & 0 & 1297 & 0 \\
\hline
\end{tabular}

The mechanisms that drive down emissions below the EU climate targets are easy to understand: a renewable energy subsidy triggers more supply of renewable electricity. This tends to decrease the prices of electricity, thereby replacing fossil fuel electricity with renewable electricity. A tax on energy consumption shifts demand for energy inward, thereby reducing demand for fossil (and non-fossil) energy. Hence, $\mathrm{CO}_{2}$ emissions are reduced. While these are theory-based arguments, a numerical model is required to quantify the effects.

Whereas the equilibrium emissions prices are identical (zero) in the ETS and the non-ETS sectors, this does not imply that the emissions reduction is cost-efficient. As is well known, a cost-efficient emissions reduction requires that marginal cost of emissions reduction is equalized between the ETS and the non-ETS sectors. There is no reason to believe that this is accomplished when the emissions reduction is generated from a higher share of renewables and improved energy efficiency. If we impose one policy goal only, namely that total emissions should be equal to that in the Reference scenario, then the marginal cost of emissions reduction will be equalized across sectors; the resulting distribution of emissions between the ETS and the non-ETS sectors will differ from that in the Reference scenario; see the discussion in Section 6.3.

Table 4 also shows the renewable subsidy offered to reach the renewable target $€ 52 /$ MWh in the Reference scenario. Moreover, the end-user energy tax imposed to reach the energy efficiency target— $€ 1297 /$ toe, which corresponds to $€ 112 / \mathrm{MWh}$.

End-user prices for energy goods are shown in Figure 2. As seen, the prices in the Reference scenario are much higher than the observed 2009 prices; this is because of the end-user tax. From Table 4 we can calculate the renewable subsidy and the end-user tax as percentages of enduser prices. We find that the renewable subsidy, which is offered to renewable electricity producers, amounts to 26 percent of the end-user price of electricity. The end-user tax corresponds to 54 percent of the end-user price of electricity, or alternatively, 79 percent of the end-user price of steam coal and 74 percent of the end-user price of natural gas.

of renewables; iii) clean, safe, and connected mobility; iv) competitive industry and a circular economy; v) infrastructure and interconnections; vi) bioeconomy and natural carbon sinks; and vii) CCS to address remaining emissions. While all these actions tend to reduce emissions, standard economic theory suggests that such a package is not cost-efficient. 
Figure 2: Consumer prices in EU-30 (€2009/toe)

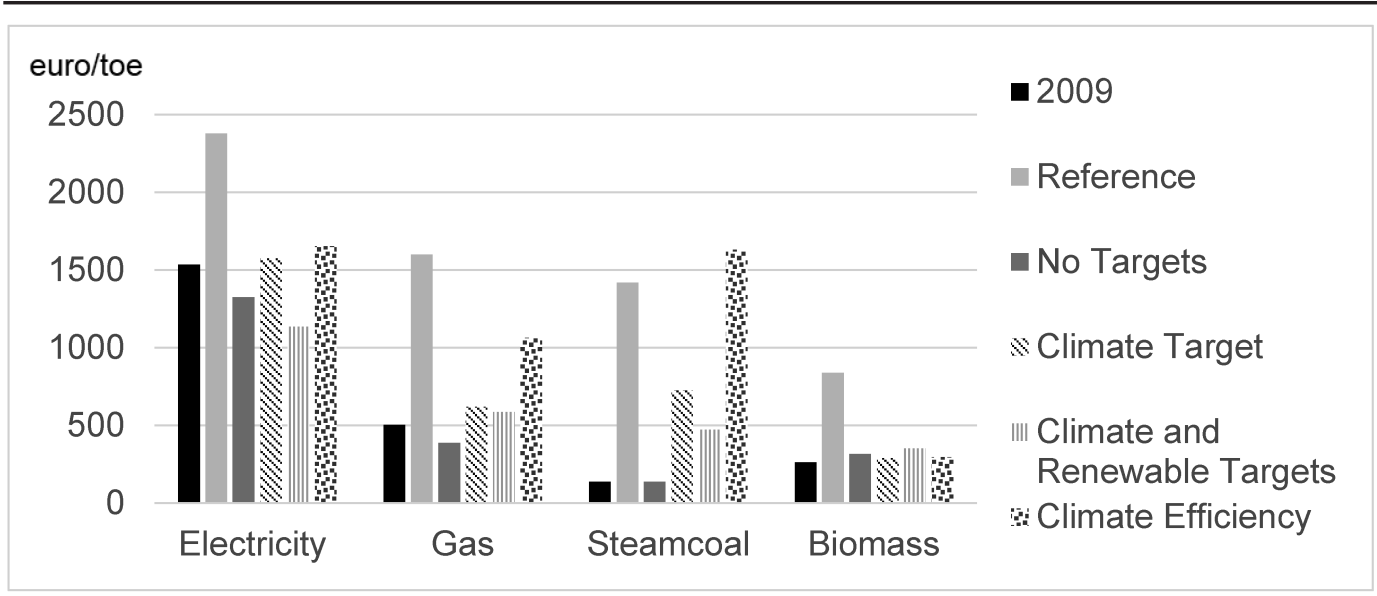

There is an increase in total production of electricity from 2009 to the equilibrium in the Reference scenario of 13 percent (Figure 3). The main reason is economic growth, which, adjusted for technology improvements among end users, raises demand for electricity. Without any policy targets, equilibrium production in 2030 would have been 41 percent above the 2009 level, see the No Targets scenario in Figure 3. The moderate increase in electricity production in the Reference scenario reflects primarily the heavy end-user tax on energy consumption, which reduces the demand for electricity.

\section{Figure 3: Electricity production in EU-30 in 2009 and 2030 (TWh)}

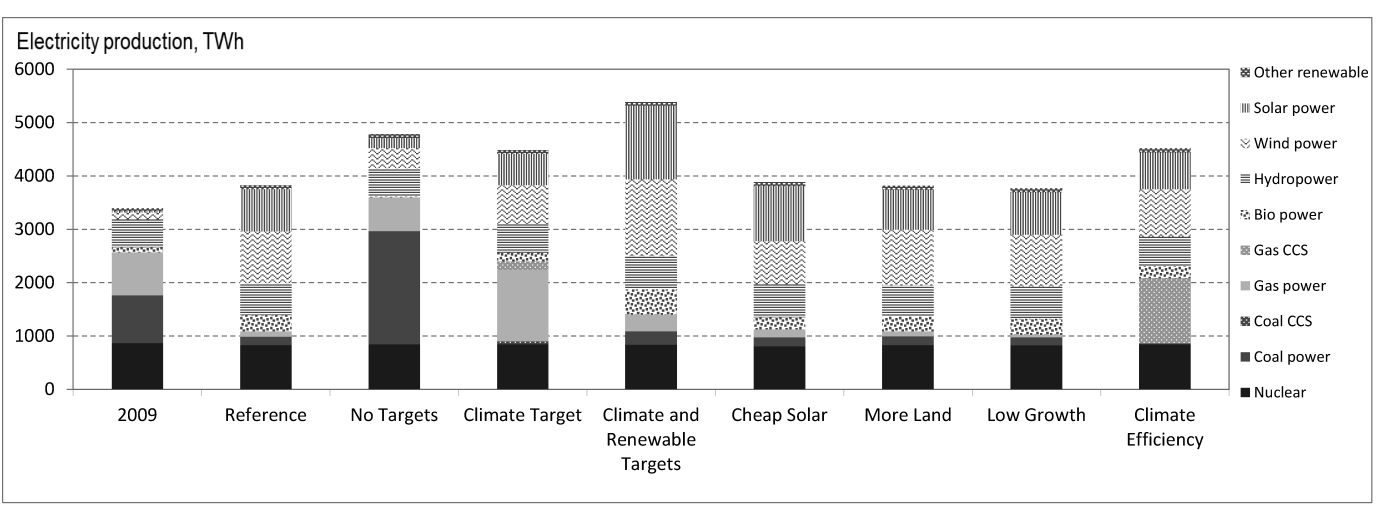

The combination of the renewable subsidy and the tax on end-user demand for energy has a significant impact on the composition of electricity technologies. Compared with 2009, the market share of both wind and solar power has increased by 21 percentage points, whereas the market share of biopower has increased by 5 percentage points. In contrast, the market share of coal power and gas power has decreased by 22 and 21 percentage points, respectively. Whereas the increase in total electricity production is "only" 13 percent (see the discussion above), total power capacity in the Reference scenario is as much is 80 percent above the level in 2009. The radical increase in power capacity reflects the low full-load hours of wind power and solar; the rate of capacity utilization of wind power and solar, which is typically less than 20 percent, is much lower than the 2009 capacity utilization rates of coal and gas power. 
The significant changes in the market shares of electricity technologies reflect that, in LIBEMOD, there is substantial flexibility in the electricity generation sector. Here, LIBEMOD specifies a number of alternative technologies. The composition of these may change radically if prices are altered: for one price vector, a technology may become profitable and is thus phased in, whereas for another price vector, a technology may become unprofitable and is thus phased out.

In contrast to the electricity generation sector, in LIBEMOD, end-user demand is derived from nested CES utility functions, and hence there is no direct substitution between technologies. With a CES utility function, even a moderate change in consumption requires significant price changes. However, in the real world, large changes in end-user prices may trigger a switch to alternative technologies, for example, installation of rooftop solar panels or acquisition of electric vehicles. Because LIBEMOD neglects end-user technology substitution, the change in consumption share by energy carrier is more modest than the change in market share by electricity technology.

\subsection{Comparison with other studies}

In Section 2.1, we referred to studies examining different aspects of the $2030 \mathrm{EU}$ energy policy package. We now provide a more detailed discussion of some of these studies and compare a selection of their results with corresponding results in our study.

PRIMES (2019) analyzes the effects of achieving the 2030 EU energy policy package using the EU-wide partial energy market model PRIMES. Whereas emissions reductions in the ETS sectors are obtained through imposing carbon prices - for 2030 these are set to $€_{2013} 28$ - command-and-control policies are used in the non-ETS sectors to reach climate targets. Here, policies include "rate and depth of buildings renovation," "eco-design standards," and "application of best available technologies" (see Table 1 in PRIMES (2019)). That study estimates a GHG emissions reduction by 2030 of 46 percent, that is, 4 percentage points less than we obtain. Furthermore, the end-user price of electricity in PRIMES (2019) is $€_{2013} 163 / \mathrm{MWh}$ in 2030, which is about 25 percent lower than the end-user price in our LIBEMOD study. The difference reflects primarily the high enduser tax imposed in the LIBEMOD study to reach the energy efficiency target.

ECF (2011) investigates changes in the European power market by 2030 that are considered to be consistent with the EU 2050 target of reducing GHG emissions. The ECF study finds that substantial investment between 2020 and 2030 in both electricity production capacity and electricity interconnectors is necessary to achieve the EU $2050 \mathrm{CO}_{2}$ emissions reduction target in the power sector, that is, a 95 percent cut relative to $1990 .{ }^{17}$ For the period 2010-2030, investment in international electricity transmission should be $173 \mathrm{GW}$, which is $37 \mathrm{GW}$ more than we obtain for the period 2009-2030.

Table 5 shows market share by technology in 2030 in our study, PRIMES (2019), and ECF (2011). The main difference between our study and PRIMES (2019) is that the latter has a much higher market share for fossil fuel-based electricity ( 23 percent vs. 7 percent in our study), whereas we have a much higher market share for solar (21 percent vs. 11 percent in PRIMES). The ECF study has an even higher market share for fossil fuel-based electricity than PRIMES (34 percent vs. 23 percent in PRIMES), whereas the market share of solar is only 6 percent in ECF (2011).

Sandbag (2019) argues that climate policies already agreed upon by the EU and its member states are on track to deliver a 50 percent GHG emissions reduction by 2030 . Half of the cut is obtained in the power sector. According to Sandbag (2019), the main difference between the PRIMES

17. According to European Commission (2011), by 2030, emissions reductions in the electricity sector should be in the range 54-68 percent (relative to 1990).

Open Access Article 
Table 5: Market share of electricity technologies in 2030

\begin{tabular}{lccc}
\hline Technology & LIBEMOD & PRIMES (2019) & ECF (2011) \\
\hline Nuclear & 22 & 21 & 16 \\
Coal power & 4 & 12 & 6 \\
Gas power & 3 & 11 & 28 \\
Biomass power & 9 & 8 & 10 \\
Hydro & 16 & 11 & 11 \\
Wind power & 25 & 26 & 22 \\
Solar power & 21 & 11 & 6 \\
\hline
\end{tabular}

(2019) estimate of a 46 percent GHG emissions reduction and the 50 percent reduction in Sandbag (2019) is that the latter takes into account all announced coal phaseouts by 2030. Thus, Sandbag (2019) has 198 TWh of coal power in 2030, whereas the PRIMES estimate is 371 TWh. Our estimate of coal power production is even lower than in the Sandbag study, namely 158 TWh, which reflects the substantial renewable subsidy.

By imposing alternative model assumptions in the Sandbag model on coal phaseout dates, energy efficiency, renewable energy penetration, electric vehicle penetration, and carbon prices, two scenarios are constructed: a "moderate" scenario with a 53 percent cut by 2030, and an "advanced" scenario with a 58 percent cut by 2030 . While these numbers exceed our estimate of a 50 percent cut, they are not directly comparable because the Sandbag study does not examine the implications of the EU renewables and energy efficiency targets, as we do.

\subsection{Robustness of Reference scenario}

In this subsection, we study three scenarios that have the same policy targets as the Reference scenario, but they differ from the Reference scenario with respect to parameter values for i) solar power, ii) land availability for wind power and solar power parks, and iii) GDP growth rates.

\section{Cheap Solar}

The cost of solar power has decreased substantially over the last 10-15 years; see, for example, Figure S5 in IRENA (2019), p. 22. Whereas experts agree that solar costs in 2030 will be significantly lower than today, it is still highly uncertain what the 2030 cost will be. Therefore, in the Cheap Solar scenario, costs of solar are cut by one-third relative to the Reference scenario (Table 3).

With the lower cost of solar power, the market share of solar increases by 6 percentage points (relative to the Reference scenario), that is, its market share is now as high as 27 percent. Increased solar production mainly reduces other sources of renewable electricity supply (Figure 3 ); the market share of wind falls by 4 percentage points, whereas the reduction in biopower is 2 percentage points. The lower cost of solar allows a lower renewable subsidy; the drop is almost 20 percent. Because the supply of electricity has become cheaper, total electricity supply increases, but the change is modest ( 2 percent). The EU-30 producer price of electricity falls by a few percent, whereas the EU-30 end-user price of electricity, which is much higher than the producer price because of end-user taxes, falls even less (measured in percent).

\section{More Land}

The development of wind and solar parks requires land. In the Reference scenario, it is assumed that in each grid cells (which covers roughly $2500 \mathrm{~km}^{2}$ ), 5 percent of the (gross) land can be used for wind parks (then $1 \mathrm{GW}$ wind power capacity can be installed in each grid cell), whereas 
1 percent of the land can be used for solar parks (then $2.5 \mathrm{GW}$ solar capacity can be installed in each grid cell) (see Appendix B). Needless to say, future land regulation for renewable electricity is highly uncertain. We test the importance of land regulation by exploring the impact of allowing 10 percent of the land in each grid cell to be used for wind parks (as opposed to 5 percent in the Reference scenario). The corresponding assumption for solar parks is 2 percent (as opposed to 1 percent in the Reference scenario). This scenario is termed More Land.

With more land available for wind and solar development, the competitive position of wind power is strengthened. The competitive position of solar is weakened relative to wind power, but strengthened relative to other technologies. ${ }^{18} \mathrm{We}$ find that total electricity production hardly changes (relative to the Reference scenario), see Figure 3, whereas wind power increases its market share by 2 percentage points and gas power and biopower lose market share. As expected, with more competitive wind and solar power, there is a drop in the renewable subsidy (by 5 percent relative to the Reference scenario), whereas other variables hardly change. ${ }^{19}$

\section{Low Growth}

In LIBEMOD, the national CES demand systems in 2030 reflect GDP growth rates between the years 2009 and 2030. For the period 2009-2017, these are observed growth rates taken from International Monetary Fund (2019), whereas the expected rates for 2018-2024 and 2025-2030 are taken from International Monetary Fund $(2018 ; 2019)$ and OECD (2018), respectively. Because the growth rates up to 2030 are uncertain - there may, for example, be another financial crisis or a pandemic - we run a scenario where the expected growth in GDP (for the period 2018-2030) is cut by 50 percent in each country (relative to the Reference scenario). Below, this scenario is referred to as Low Growth (Table 3).

With substantially lower economic growth than in the Reference scenario, energy demand is reduced. Hence, the energy consumption tax, which is imposed to reach the energy efficiency target, is much lower ( 24 percent) than in the Reference scenario. The tax effect is so strong that energy consumption in the Low Growth scenario is just marginally below the level in the Reference scenario. For other variables, the difference from the Reference scenario is marginal. For example, carbon emissions are slightly lower than in the Reference scenario, and hence also in the Low Growth scenario carbon prices are zero.

\section{ROBUSTNESS OF POLICY TARGETS}

In Section 5.3 we studied the robustness of the Reference scenario by examining scenarios where at least one LIBEMOD parameter had a different value than in the Reference scenario, but policy targets were the same as in the Reference scenario. In this Section we undertake a different type of robustness: we study scenarios where policy targets differ from the targets in the Reference scenario, but all LIBEMOD parameters take the same values as in the Reference scenario.

18. With our calibration procedure for wind and solar power (see Appendix B), these assumptions imply that maximum wind and solar production in a country (of course) doubles. Technically, the parameters $b_{w}$ and $b_{s}$, which reflect how a unit increase in capacity lowers the number of full-load hours of wind power and solar, are halved. A lower $b$ strengthen, cet. par., the competitive position of the associated technology. However, because $b_{w}>b_{s}$, wind power gains more than solar from a 50 percent cut in the parameter value.

19. If, alternatively, land availability for wind and solar parks is reduced by 50 percent relative to the Reference scenario, then the quantitative effects are rather similar to the ones in the More Land Scenario, but, of course, all signs are reversed. For example, the market share of wind power decreases by three percentage points (relative to the Reference scenario). 


\subsection{Decomposition of the policy targets of the Reference scenario}

In the Reference scenario, we examined the effects of a GHG emissions reduction of (at least) 40 percent, combined with a renewable share in final energy consumption of 32 percent, and an improvement in energy efficiency of 32.5 percent. To understand the partial effects of different policy targets, we now introduce three alternative scenarios that decompose the policy goals in the Reference scenario.

First, we remove all the policy goals in the Reference scenario; this scenario is termed No Targets (Table 3). Next, we introduce the ETS and non-ETS emissions targets, which are implemented by one ETS quota price and one non-ETS $\mathrm{CO}_{2}$ tax; this is the Climate Targets scenario. Finally, we add the goal of a renewable share of 32 percent in final energy demand to the climate targets; the resulting scenario is termed Climate and Renewable Targets. As in the Reference scenario, the warranted renewable share is reached through a renewable subsidy.

Table 4 shows the decomposition of the policy goals of the Reference scenario. Without any policy targets (No Targets), GHG emissions would be 2 percent lower in 2030 than in 1990 and the renewable share in final energy consumption would be 11 percent; this outcome reflects the low cost of wind and solar power in 2030 as well as exogenous improvements in end-user technologies. Relative to the 2009 outcome, electricity supply increases (Figure 3).

Without any emissions targets, the price of emissions is zero, by construction. If, alternatively, the ETS and non-ETS emissions goals are imposed (Climate Targets), then, by construction, GHG emissions in 2030 are 40 percent lower than in 1990. The $\mathrm{CO}_{2}$ prices needed to achieve the emissions goals would be $€ 62 / \mathrm{tCO}_{2}$ in the ETS sectors and $€ 262 / \mathrm{tCO}_{2}$ in the non-ETS sectors (Table 4). The difference in $\mathrm{CO}_{2}$ prices reflects substantial technology flexibility in the electricity sector (which is part of the ETS sectors); this is in contrast to the non-ETS sectors in LIBEMOD where emissions can be reduced through higher energy prices only. The emissions prices of $€ 62$ and $€ 262 / \mathrm{tCO}_{2}$ would, through a lower supply of fossil energy, lead to a renewable share of 24 percent, whereas the improvement in energy efficiency would be 17 percent (Table 4).

If, in addition to the two GHG emissions targets, a renewable share of 32 percent is imposed (Climate and Renewable Targets), then electricity production becomes higher than in the Climate Targets scenario (because of the renewable subsidy) (Figure 3) ${ }^{20}$ In the Climate and Renewable Targets scenario, emissions prices in the ETS and non-ETS sectors are $€ 14$ and $€ 267 / \mathrm{tCO}_{2}$, respectively (Table 4). The ETS price is lower than in the Climate Targets scenario because with a renewable subsidy (offered in order to reach the renewable target), supply of renewable electricity is stimulated. Therefore, the price of electricity decreases and low-efficiency fossil fuel plants become nonprofitable. With lower supply of fossil electricity, the prices of emissions should be reduced in order to reach the same emissions target.

Note that the carbon price in the non-ETS sectors is slightly higher in the Climate and Renewable Targets scenario than in the Climate Targets scenario ( $€ 267$ vs. $€ 262 / \mathrm{tCO}_{2}$ ). When the renewable target is imposed (in addition to the climate targets), supply of fossil-based electricity decreases (see previous paragraph). Therefore, the price of fossil fuels drops, which tends to increase

20. Imposing the renewable target increases (annual) consumer surplus by 204 billion $€$ (relative to the Climate Target scenario) because of lower consumer prices. However, government net income decreases by 290 billion $€$ (relative to the Climate Target scenario) because of a significantly lower carbon price in the ETS sectors and also because of government expenses to support renewable power production. When all groups are taken into account, that is, also energy producers and traders, we find that total welfare decreases by 28 billion $€$, which corresponds to roughly 0.1 percent of GDP in EU-30. In Section 2.1, we referred to Boeters and Koornneef (2011) who conclude that cost will increase if a 20 percent renewable share is imposed in addition to a 20 percent emissions reduction for the EU in 2020. Hence, this is the same type of result as ours.

Open Access Article 
demand for fossil fuels in the end-user sectors. To meet the GHG emissions target in the non-ETS sectors, the non-ETS emissions price should increase.

Finally, with all four targets imposed (Reference scenario), the emissions reduction would be greater than the minimum requirements, and thus the prices of $\mathrm{CO}_{2}$ emissions are zero (see Section 4). In fact, total reduction in GHG emissions would be 50 percent. Both electricity production and total energy consumption are lower in the Reference scenario than in the other 2030 scenarios referred to above.

\subsection{Alternative renewable and energy efficiency targets}

As discussed in Section 2, there have been heated debates in the EU on whether a renewable target and an improvement in energy efficiency should be imposed for 2030, and if so, how ambitious these targets should be. Therefore, we discuss below the implications of alternative energy policy targets.

First, we explore the effects of an alternative renewable share in final energy consumption. We impose that energy efficiency should be improved by 32.5 percent (as in the Reference scenario), and further that emissions in the ETS (non-ETS) sectors are at least 43 percent (30 percent) lower than in 2005 (as in the Reference scenario). Under these assumptions, we study how emissions change as the renewable share is altered.

Next, we study the impact of alternative improvements in energy efficiency. Now we vary the energy efficiency improvement, keeping the renewable share in final energy demand fixed at 32 percent, whereas emissions in the ETS (non-ETS) sectors are at least 43 percent (30 percent) lower than in 2005. Under these assumptions, we study how emissions change as the improvement in energy efficiency is altered.

The implications of alternative renewable shares in final energy consumption are shown in Figure 4. Here, equilibrium emissions in the ETS and non-ETS sectors in the Reference scenario are both set equal to one. As the renewable share is increased from 32 percent, there is a modest drop in ETS emissions, whereas there is a negligible drop in non-ETS emissions. The difference reflects that there are substantial technology-switching options in the ETS sectors in LIBEMOD, which is not the case in the non-ETS sectors.

If the renewable share is decreased from 32 percent, there is a negligible increase in nonETS emissions. Furthermore, ETS emissions increase if the renewable share is decreased from 32 percent, and this effect is much stronger than in the non-ETS sectors (Figure 4). Note that if the renewable share is 23 percent, ETS emissions are exactly 43 percent below their 2005 value. Hence, for renewable shares below 23 percent, it is necessary to have a positive price on $\mathrm{CO}_{2}$ emissions in the ETS sector to meet the requirement that ETS emissions should be (at least) 43 percent lower than in 2005. Furthermore, for a renewable share below 20 percent, it is also necessary to have a positive price on $\mathrm{CO}_{2}$ emissions in the non-ETS sectors to ensure that these emissions are (at least) 30 percent lower than in 2005.

Figure 5 shows the end-user energy tax and the renewable subsidy that are required to achieve the emissions and energy efficiency targets under alternative renewable targets. In the figure, the equilibrium values of the instruments in the Reference scenario have been normalized to one. As seen from Figure 5, if the renewable target is lower than in the Reference scenario, then the magnitude of both policy instruments should also be lower than in the Reference scenario.

From Figure 4 we know that if the renewable share is 23 percent, ETS emissions are exactly 43 percent below their 2005 value. Then the renewable subsidy is at least 60 percent lower than 
Figure 4: Sensitivity of renewable share in final energy consumption-emissions

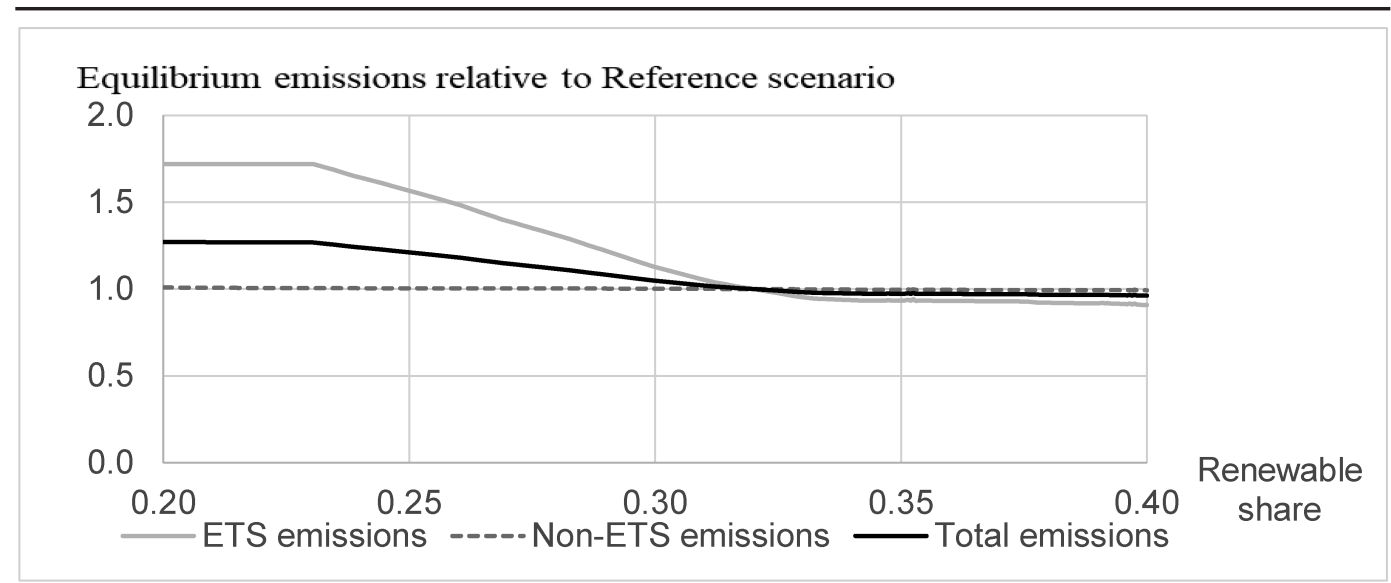

Equilibrium relationships between (i) the share of renewables in final energy consumption and (ii) emissions in the ETS sectors and the non-ETS sectors when the energy efficiency improvement is fixed at 32.5 percent. Emissions in the ETS and non-ETS sectors are measured relative to the corresponding equilibrium emissions in the Reference scenario.

Figure 5: Sensitivity of renewable share in final energy consumption-policy instruments

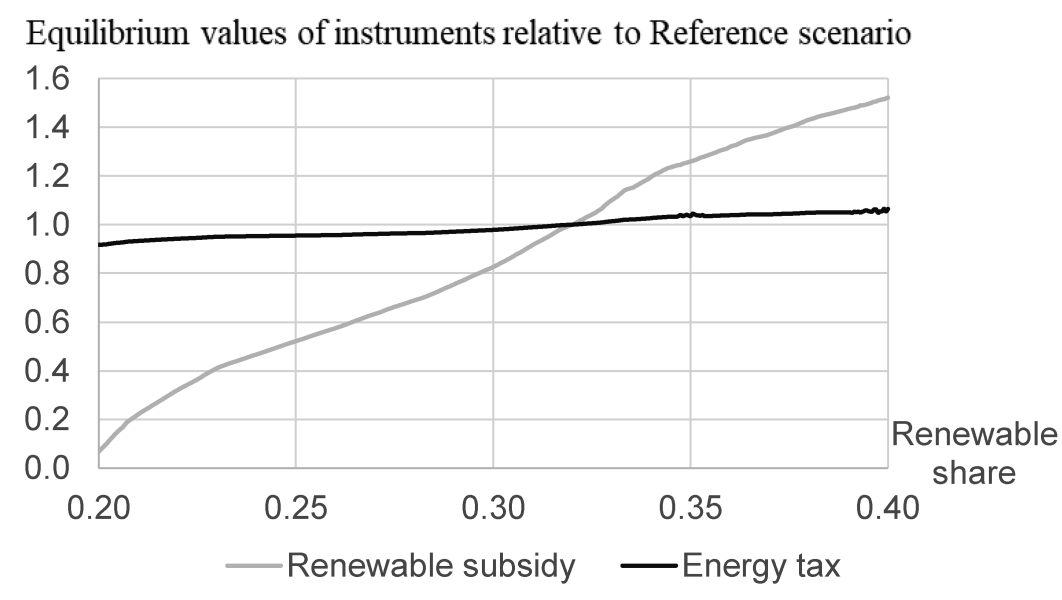

Renewable subsidy and end-user energy tax as functions of the renewable share in final energy consumption when the energy efficiency improvement is fixed at 32.5 percent and the emissions targets of the ETS and non-ETS sectors are met.

in the Reference scenario, whereas the end-user tax is slightly lower than in the Reference scenario (Figure 5).

Figure 6 shows the effects on emissions of alternative targets for improved energy efficiency when the renewable share in final energy consumption is 32 percent. In the figure, equilibrium emissions in the ETS and non-ETS sectors are set equal to one. From Figure 6 we see that a higher energy efficiency improvement than 32.5 percent will lower emissions in both the ETS and non-ETS sectors slightly relative to the outcome in the Reference scenario. Alternatively, an imposed improvement in energy efficiency lower than 32.5 percent will increase emissions in both sectors (relative to the outcome in the Reference scenario). Note, however, that if the improvement in energy efficiency is 25 percent or lower, then the non-ETS emissions restriction bites, that is, 
Figure 6: Sensitivity of energy efficiency target—emissions

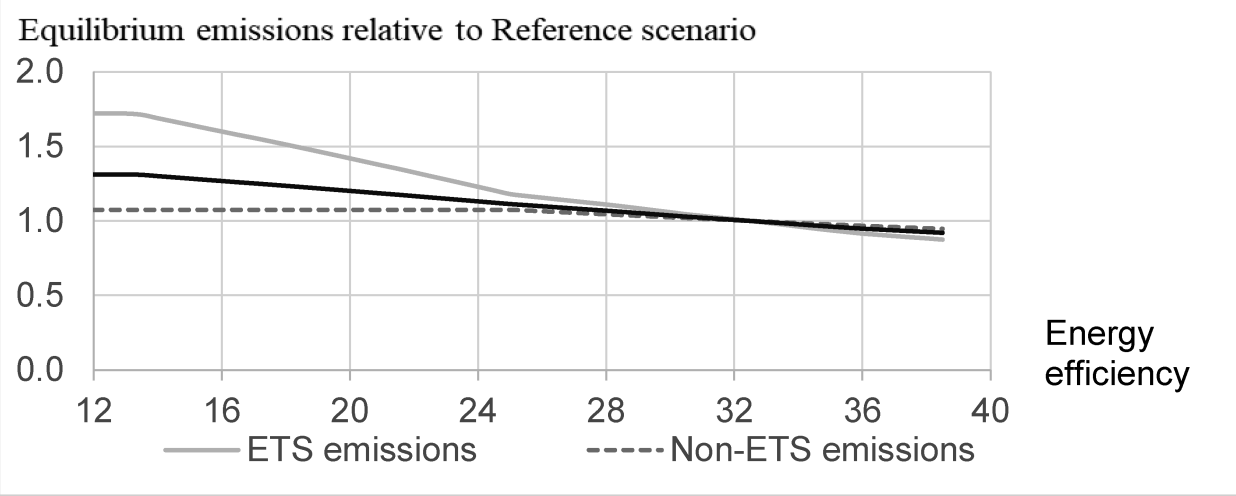

Equilibrium relationships between (i) the improvement in energy efficiency and (ii) emissions in the ETS sectors and the non-ETS sectors when the renewable share in final energy consumption is fixed at 32 percent. Emissions in the ETS and non-ETS sectors are measured relative to the corresponding equilibrium emissions in the Reference scenario.

\section{Figure 7: Sensitivity of energy efficiency target-policy instruments}

Equilibrium values of instruments relative to Reference scenario

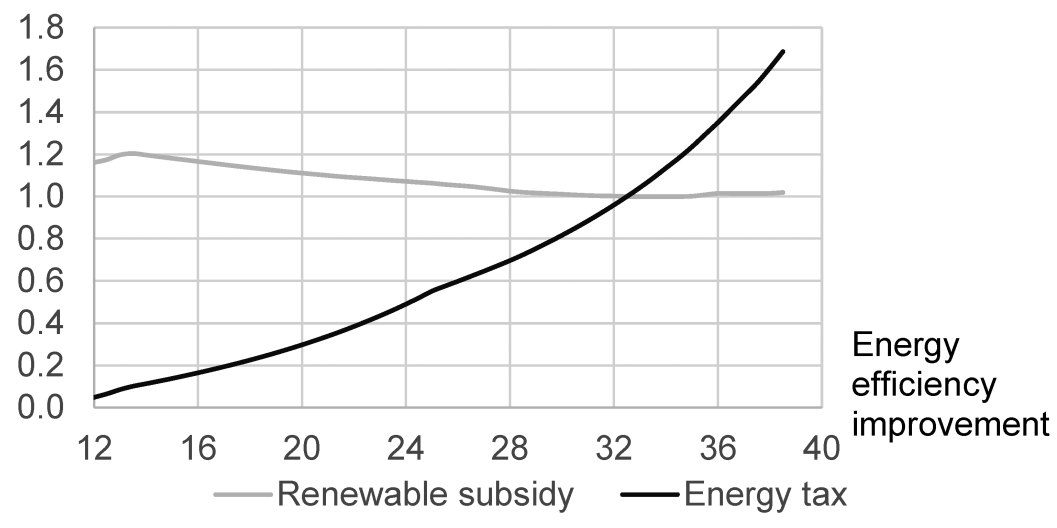

Renewable subsidy and end-user energy tax as functions of the energy efficiency improvement when the renewable share in final energy consumption is fixed at 32 percent and the emissions targets of the ETS and non-ETS sectors are met.

emissions are exactly 30 percent lower than in 2005. This is accomplished through a $\mathrm{CO}_{2}$ price on non-ETS emissions. Hence, the $\mathrm{CO}_{2}$ price in the non-ETS sectors is zero if the improvement in energy efficiency is exactly 25 percent, and positive if the improvement in energy efficiency is less than 25 percent. Furthermore, if the improvement in energy efficiency is 13 percent or lower, then the ETS emissions restriction becomes binding, that is, ETS emissions are exactly 43 percent lower than in 2005. This is accomplished through a $\mathrm{CO}_{2}$ price on ETS emissions.

Figure 7 shows how the renewable subsidy and the energy tax vary with the improvement in energy efficiency. Here, the renewable subsidy and the end-user energy tax in the Reference scenario are set equal to one. A higher required improvement in energy efficiency, which implies lower consumption of primary energy, is accomplished through a higher tax on energy consumption. As seen from Figure 7, the energy tax is close to zero if the imposed improvement is as low as 12 per- 
cent. ${ }^{21}$ Finally, as seen from Figure 7, if the imposed improvement in energy efficiency is increased, the renewable subsidy should in general be lowered; with improved energy efficiency, demand for energy decreases and thus production of fossil energy is reduced. Hence, it is easier to reach the renewable target. The renewable subsidy can therefore be lowered. ${ }^{22}$

\subsection{Climate efficiency}

As discussed in Section 5.1, the emissions reduction in the Reference scenario is not cost-efficient. Therefore, we have examined a scenario termed Climate Efficiency where total GHG emissions are reduced by 50 percent (as in the Reference equilibrium), but without imposing any other targets, that is, there are no specific ETS and non-ETS emissions requirements (only a requirement on total emissions) and no restrictions on the share of renewables, nor on the improvement in energy efficiency. We find that the common $\mathrm{CO}_{2}$ price has to be as high as $€ 322 / \mathrm{tCO}_{2}$, which is even greater than the non-ETS price in the Climate Targets scenario $\left(€ 267 / \mathrm{tCO}_{2}\right)($ Table 4).

Why is the carbon tax so high in the Climate Efficiency scenario? In contrast to the Reference scenario, there is no renewable subsidy in the Climate Efficiency scenario; such a subsidy tends to decrease the price of electricity, thereby phasing out some of the fossil-based supply of electricity. Furthermore, in contrast to the Reference scenario, there is no (additional) tax on end-user consumption of energy in the Climate Efficiency scenario; such a tax tends to decrease demand for energy, thereby reducing fossil-based consumption. Without a renewable subsidy and an end-user tax, the carbon tax in the Climate Efficiency scenario must solely ensure a 50 percent emissions reduction.

Furthermore, in LIBEMOD, there is technology switching in the electricity generation sector but not in the end-user sectors where demand for fuels is represented by rigid CES systems. Therefore, a "moderate" price of emissions will generate a large emissions reduction in the electricity generation sector, whereas a "very high" price of emissions is required to obtain a large emissions reduction in the end-user sectors. Because the electricity generation sector accounts for a moderate share of total emissions, a high price of emissions is required to obtain a 50 percent GHG emissions reduction.

Note that electricity production is higher in the Climate Efficiency scenario than in the Reference scenario (Figures 3). The ranking reflects the efficiency gain of imposing a common $\mathrm{CO}_{2}$ price for all sectors.

Finally, we have compared welfare in the Climate Efficiency scenario with welfare in the Reference scenario. In the Climate Efficiency scenario, the annual consumer surplus, aggregated over all end-user sectors, is $€ 596$ billion (i.e., $€ 5961000$ million) above the corresponding value in the Reference scenario, see Table C.1 in Appendix C. The increase reflects lower consumer prices in the Climate Efficiency scenario than in the Reference scenario. In contrast, the annual decrease in government net income (relative to the Reference scenario) is $€ 530$ billion. Here, there are several counteracting effects when moving from the Reference scenario to the Climate Efficiency scenario: no income from a tax on end-user consumption (which lowers government net income), no payment of renewable subsidies (which increases government net income), and a higher $\mathrm{CO}_{2}$ price (which

21. For energy-efficiency improvements below 10.5 percent, the associated energy tax is zero.

22. As seen from Figure 7, if the improvement in energy efficiency is raised slightly from 12 percent, then the renewable subsidy should be increased marginally. This effect reflects that for energy-efficiency improvements between 12 and 14 percent, there is a positive $\mathrm{CO}_{2}$ price in the ETS sectors. When the energy-efficiency target is increased slightly from 12 percent, the $\mathrm{CO}_{2}$ price (necessary to meet the ETS emissions target) is decreased, thereby strengthening the competitive position of fossil energy relative to renewable energy. Therefore, the renewable subsidy has to be greater in order to reach the renewable target of 32 percent. 
increases government net income). Our result shows that the first effect dominates, that is, government net income is greater in the Reference scenario than in the Climate Efficiency scenario. The net effect for other welfare components (i.e., surplus for electricity producers, surplus for other energy producers, and trader surplus) is positive but smaller, and adds up to $€ 46$ billion. When all welfare components are taken into account, we find that annual welfare is $€ 111$ billion higher in the Climate Efficiency scenario than in the Reference scenario, which corresponds to roughly 0.5 percent of GDP in EU-30. For a discussion on welfare by country in the Climate Efficiency scenario relative to the Reference scenario, see Appendix C, part I. In Appendix C we also explore how a renewable subsidy and an end-user tax work in the Climate Efficiency scenario.

\section{CONCLUDING REMARKS}

This paper has examined the impact of the 2030 EU climate and energy policy package: (i) GHG emissions should be (at least) 40 percent lower in 2030 than in 1990, which has been specified as ETS (non-ETS) emissions should be 43 (30) percent lower than in 2005; (ii) the renewable share in final energy demand should be 32 percent; and (iii) the improvement in energy efficiency should be 32.5 percent (relative to 2005). To this end, we have used the numerical multimarket, multiperiod equilibrium model LIBEMOD, which gives a detailed description of the energy markets in EU-30 (electricity, natural gas, coal and biomass) along with modeling of the global markets for coal, oil, and biofuels. This model determines investment, extraction, production, trade, and consumption of energy goods in each of 30 European countries, along with consistent equilibrium prices that clear all markets, including tariffs for the international transportation of natural gas and electricity.

We find that the renewable and energy efficiency targets have been set so high that the derived emissions reductions in the ETS and non-ETS sectors exceed their targets. Hence, carbon prices are zero. In fact, total GHG emissions reduction is 50 percent, that is, 10 percentage points higher than the goal of the EU. The renewable subsidy required to achieve a renewable share in final energy demand of 32 percent is $€_{2009} 52 / \mathrm{MWh}$, whereas the uniform tax on energy consumption has to be $€_{2009} 1297 /$ toe $\left(€_{2009} 112 / \mathrm{MWh}\right)$ to achieve the required improvement in energy efficiency.

Because there have been intense debates in the EU on whether an energy efficiency target should be part of the 2030 package, and how ambitious the renewable policy should be, we have examined the impact on the 2030 equilibrium under alternative assumptions about the improvement in energy efficiency and the share of renewables in final energy consumption. We find that if the improvement in energy efficiency is 32.5 percent, and the renewable share in final energy demand is only 23 percent, then ETS emissions are exactly 43 percent below the 2005 level, which is the EU 2030 emissions target. Similarly, if the renewable share in final energy consumption is 32 percent, and the improvement in energy efficiency is only 13 percent, then ETS emissions are exactly 43 percent below the 2005 level.

Throughout the paper, we have assumed EU-wide policy instruments. This is fine with respect to the EU-wide climate target for the ETS sectors, which, according to the EU, should be reached by an EU-wide tradable permit system, namely the EU ETS. For the EU-wide renewables and energy efficiency targets, the basic idea of the EU is to let countries select policy instruments and use the EU governance system to ensure that EU-wide targets are met. While a governance regulation has been passed requiring each member state to draft integrated 10-year national energy and climate plans for 2021-2030 (Eur-lex (2018c)), it is not quite clear how the potential conflict between EU-wide targets and discretionary domestic policy instruments will be handled. If the EU believes implemented domestic instruments are too lax to achieve the EU-wide targets, which 
countries will be instructed to impose a stricter policy and how much should domestic instruments be adjusted? The basic assumption of the present paper is that the EU system will work out a solution; our specific choice of instruments should be seen as a way to model sufficient incentives for the agents to reach the policy goals. For a discussion on the EU governance system, see Ringel and Knodt (2018). Based on a review of stakeholder positions, this paper finds strong acceptance for enhanced coordination.

Needless to say, other scenarios than those studied are possible. One direction is to allow for uncertainty in LIBEMOD (Brekke et al. (2017)). Another option is to deviate from the assumption of competitive markets. The EU has for years aimed at transforming the European electricity and natural gas markets into efficient ("internal") markets. However, the transition has been partial and incremental. In particular, there have been setbacks because of concerns about national interests and energy security; see, for example, European Commission (2010). This suggests running LIBEMOD under different assumptions about market structure; in LIBEMOD, the market structure can be represented by a set of parameters that reflect the degree of deviation from the competitive outcome in the European energy sector; see Golombek et al. (2013a).

In the present study, the LIBEMOD model has been developed to be suitable for analyzing the 2030 EU climate and energy package, with its emphasis on renewable energy. The model has previously been used to analyze a number of issues: for example, the potential for CCS in the European electricity market (Golombek et al. 2011); how climate change may impact the future European electricity market (Golombek et al. 2012); the importance of EU rules on emission quota allocation (Golombek et al. 2013b); and the Russian energy market and its impact on the European energy market (Aune et al. 2015; 2017). Needless to say, the model can be developed to analyze a number of topics related to the future European energy market: for example, (i) electrification of different means of transportation, which will impact both the demand for and supply of electricity; (ii) rooftop PV as a source of heating and cooling and the resulting effects in the energy markets; (iii) integration of electricity and heat markets; and (iv) how imports of cheap shale gas can crowd out European natural gas supply and the derived implications for Europe as well as Russia.

Finally, the 2030 EU target of a 40 percent GHG emissions reduction may be adjusted in the future. In June 2019, the EU's top energy and climate official announced that "the bloc is now set to increase the emissions reduction pledge from 40 percent by 2030 to 45 percent" (Euractiv (2019a)). However, several Central and Eastern European countries are against raising the EU target, and Germany is also against such a move, whereas climate-progressive countries such as the Netherlands and Sweden consider a 45 percent cut to be too small. The latter position is consistent with the European Parliament, which in March 2019 voted in favor of increasing the EU's 2030 emission target to 55 percent (Euractiv (2019b)). ${ }^{23}$ Therefore, in the future, the LIBEMOD model may be used to analyze more ambitious climate targets than a 40 percent emissions reduction.

\section{ACKNOWLEDGMENTS}

Earlier versions of this paper have been presented at the CREE work-shop for policy makers, DIW Berlin, the Norwegian Water Resources and Energy Directorate, and the Norwegian Min-

23. In March 2019, the European Parliament also voted in favor of a net-zero emissions target by 2050. This was strengthened in November 2019 when the Parliament approved a resolution declaring a climate and environmental emergency in Europe and globally; see European Parliament (2019). The European Parliament also wanted all relevant legislative and budgetary proposals to be fully aligned with the objective of limiting global warming to under $1.5^{\circ} \mathrm{C}$. For steering of renewable support schemes by the EU, see Boasson (2019). 
istry of Petroleum and Energy — we thank the participants for their comments. We would also like to thank Katinka Holtsmark, Taran Fæhn and three anonymous referees for comments. This research was made possible through financial support from the Research Council of Norway to the CREE centre as well as through financial support from the European Commission under the $7^{\text {th }}$ Framework Programme of the European Union to the project Economic iNsTRuments to Achieve Climate Treaties in Europe (ENTRACTE), project number 308481, see http://entracte-project.eu/.

\section{REFERENCES}

Abrell, J. and H. Weigt (2016). “The Short and Long Term Impact of Europe's Natural Gas Market on Electricity Markets until 2050.” The Energy Journal 37(SI3): 125-146. https://doi.org/10.5547/01956574.37.SI3.jabr .

Abrell, J., M. Kosch, and S. Rausch (2019). "Carbon abatement with renewables: Evaluating wind and solar subsidies in Germany and Spain.” Journal of Public Economics 169: 172-202. https://doi.org/10.1016/j.jpubeco.2018.11.007.

Ambec, S. and C. Crampes (2019). "Decarbonizing electricity generation with intermittent sources of energy." Journal of the Association of Environmental and Resource Economists 6(6): 1105-34. https://doi.org/10.1086/705536.

Andor, M.A., M. Frondel, and C. Vance (2017). “Germany's Energiewende: A Tale of Increasing Costs and Decreasing Willingness-To-Pay.” The Energy Journal 38(SI1): 211-228. https://doi.org/10.5547/01956574.38.SI1.mand.

Aune, F., R. Golombek, S.A. C. Kittelsen, and K.E. Rosendahl (2008). Liberalizing European Energy Markets: An Economic Analysis. Cheltenham, UK and Northampton, MA: Edward Elgar Publishing. https://doi.org/10.4337/9781781007648.

Aune, F.R., R. Golombek, A. Moe, K.E. Rosendahl, and H.H. Le Tissier (2015). "Liberalizing Russian Gas Markets—An Economic Analysis.” Energy Journal 36(Adelman special issue): 63-97. https://doi.org/10.5547/01956574.36.SI1.faun.

Aune, F.R., R. Golombek, A. Moe, K.E. Rosendahl, and H.H. Le Tissier (2017). “The Future of Russian Gas Exports.” Economics of Energy \& Environmental Policy 6(2): 111-134. https://doi.org/10.5547/2160-5890.6.2.faun.

Babonneau, F., A. Haurie, and M. Vielle (2018). "Welfare Implications of EU Effort Sharing Decision and Possible Impact of a Hard Brexit.” Energy Economics 74 (August): 470-489. https://doi.org/10.1016/j.eneco.2018.06.024.

Boasson, E.L. (2019). Constitutionalization and Entrepreneurship: "Explaining Increased EU Steering of Renewables Support Schemes." Politics and Governance 7(1): 70-80. https://doi.org/10.17645/pag.v7i1.1851.

Boeters, S. and J. Koornneef (2011). "Supply of Renewable Energy Sources and the Cost of EU Climate Policy." Energy Economics 33: 1024-1034. https://doi.org/10.1016/j.eneco.2011.04.005.

Böhringer, C., A. Löschel, U. Moslener, and T.F. Rutherford (2009). "EU Climate Policy up to 2020: An Economic Impact Assessment." Energy Economics, 31(Supplement 2): S295-S305. https://doi.org/10.1016/j.eneco.2009.09.009 .

Böhringer, C., F. Landis, and M.A. Tovar Reaños (2017). "Economic Impact of Renewable Energy Production in Germany." Energy Journal 38(SI1): 189-209. https://doi.org/10.5547/01956574.38.SI1.cboh.

Brekke, K.A., R. Golombek, M. Kaut, S.A.C. Kittelsen, and S.W. Wallace (2017): "Stochastic Energy Market Equilibrium Modeling with Multiple Agents." Energy 134: 984-990. https://doi.org/10.1016/j.energy.2017.06.056.

Burger, S.P., J.D. Jenkins, C. Batlle, and I.J. Pérez-Arriaga (2019a). "Restructuring Revisited Part 1: Competition in Electricity Distribution Systems." The Energy Journal 40(3): 31-54. https://doi.org/10.5547/01956574.40.3.sbur.

Burger, S.P., J.D. Jenkins, C. Batlle, and I.J. Perez-Arriaga (2019b). "Restructuring Revisited Part 2: Coordination in Electricity Distribution Systems.” The Energy Journal 40(3): 55-76. https://doi.org/10.5547/01956574.40.3.jjen.

Callaway, D.S., M. Fowlie, and G. McCormick (2018). "Location, location and location: The variable value of renewable energy and demand-side efficiency resources." Journal of the Association of Environmental and Resource Economists 5(1): 39-75. https://doi.org/10.1086/694179.

Chyong, C.K. (2019). "European Natural Gas Markets: Taking Stock and Looking Forward.” Review of Industrial Organization 55(1): 89-109. https://doi.org/10.1007/s11151-019-09697-3.

Cullen, J. (2013). "Measuring the environmental benefits of wind-generated electricity." American Economic Journal: Economic Policy 5(4): 107-133. https://doi.org/10.1257/pol.5.4.107.

De Vries, L.J. and R.A. Verzijlbergh (2018). "How Renewable Energy is Reshaping Europe's Electricity Market Design." Economics of Energy \& Environmental Policy 7(2): 31-49. https://doi.org/10.5547/2160-5890.7.2.1dev.

Duso, T., J. Seldeslachts, and F. Szucs (2019). "The Impact of Competition Policy Enforcement on the Functioning of EU Energy Markets.” The Energy Journal 40(5): 97-120. https://doi.org/10.5547/01956574.40.5.tdus.

ECF (2011). "Power Perspectives 2030. On the road to a decarbonised power sector. A contributing study to Roadmap 2050: a practical guide to a prosperous, low-carbon Europe.” European Climate Foundation. Retrieved December 16, 2019, from https://www.roadmap2050.eu/attachments/files/PowerPerspectives2030_FullReport.pdf. 
EEA (2013). “Annual European Union greenhouse gas inventory 1990-2011 and inventory report 2013.” Submission to the UNFCCC Secretariat. Technical report No 8/2013. The European Environmental Agency. Available at http://www.eea. europa.eu//publications/european-union-greenhouse-gas-inventory-2013.

Egerer, J., J. Rosellón, and W.-P. Schill (2015). "Power System Transformation toward Renewables: An Evaluation of Regulatory Approaches for Network Expansion.” The Energy Journal 36(4): 105-128. https://doi.org/10.5547/01956574.36.4. jege.

Egerer, J., C. Gerbaulet, and C. Lorenz (2016). "European Electricity Grid Infrastructure Expansion in a 2050 Context.” The Energy Journal 37(SI3): 101-124. https://doi.org/10.5547/01956574.37.SI3.jege.

Euractiv (2019a). Data retrieved December 13, 2019 from https://www.euractiv.com/section/climate-environment/news/euin-de-facto-position-to-up-emissions-reduction-from-40-to-45/.

Euractiv (2019b). Data retrieved December 9, 2019 from https://www.euractiv.com/section/climate-strategy-2050/news/euparliament-votes-for-55-emissions-cuts-by-2030/.

Eur-lex (2018a). "Directive (EU) 2018/2001 of the European parliament and of the Council of 11 December 2018 on the promotion of the use of energy from renewable sources.” Data retrieved December 10, 2019 from https://eur-lex.europa.eu/ legal-content/EN/TXT/PDF/?uri=CELEX:32018L2001\&from=EN.

Eur-lex (2018b). "Directive (EU) 2018/2001 of the European parliament and of the Council of 11 December 2018 amending Directive 2012/27/EU on energy efficiency.” Data retrieved December 10, 2019 from https://eur-lex.europa.eu/legal-content/EN/TXT/PDF/?uri=CELEX:32018L2002\&from=EN.

Eur-lex (2018c). "Regulation (EU) 2018/1999 of the European Parliament and of the Council of 11 December 2018 on the Governance of the Energy Union and Climate Action, amending Regulations (EC) No 663/2009 and (EC) No 715/2009 of the European Parliament and of the Council, Directives 94/22/EC, 98/70/EC, 2009/31/EC, 2009/73/EC, 2010/31/EU, 2012/27/EU and 2013/30/EU of the European Parliament and of the Council, Council Directives 2009/119/EC and (EU) 2015/652 and repealing Regulation (EU) No 525/2013 of the European Parliament and of the Council." Data retrieved December 10, 2019 from https:/eur-lex.europa.eu/legal-content/EN/TXT/PDF/?uri=CELEX:32018R1999\&from=EN.

Europa (2018). Data retrieved December 10, 2019 from https:/ec.europa.eu/energy/en/topics/energy-strategy-and-energy-union/2050-long-term-strategy.

Europa (2019a). Data retrieved December 10, 2019 from https://ec.europa.eu/clima/policies/strategies/2030_en.

Europa (2019b). Data retrieved December 10, 2019 from https://ec.europa.eu/energy/en/topics/energy-strategy-and-energy-union/clean-energy-all-europeans.

European Commission (2010). "Communication from the Commission to the Council and the European Parliament." Report on progress in creating the internal gas and electricity market. http://ec.europa.eu/energy/gas_electricity/doc/2010/ com_2010_0084_f_en.pdf.

European Commission (2011). "A roadmap for moving to a competitive low carbon economy in 2050.” COM (2011) 112 final. Brussels, 8.3.2011.

European Commission (2016). "Proposal for a directive of the European Parliament and of the Council, amending directive 2012/27/EU on energy efficiency." COM (2016) 761 final. Brussels, 30.11.2016.

European Commission (2019). "Energy prices and costs in Europe." Report from the Commission to the European Parliament, the Council, the European Economic and Social Committee and the Committee of the Regions. COM (2019) 1 final. Brussels, 9.01.2019. Data retrieved December 10, 2019 from https://ec.europa.eu/energy/sites/ener/files/epc_report_final_1.pdf.

European Parliament (2018). "Regulation (EU) 2018/842 of the European Parliament and of the Council of 30 May 2018."

European Parliament (2019). Data retrieved 9 December 2019 from https://www.europarl.europa.eu/news/en/pressroom/20191121IPR67110/the-european-parliament-declares-climate-emergency.

Fraunhofer (2019). Data Retrieved April 1, 2019 from http://windmonitor.iee.fraunhofer.de/windmonitor_en/3_Onshore/5_ betriebsergebnisse/1_volllaststunden.

Gaure, S. and R. Golombek (2019). “True or not true: Carbon-free electricity generation is possible.” CREE Working Paper $11 / 2019$.

Gelaro, R., W. McCarty, M.J. Suárez, R. Todling, A. Molod, L. Takacs, C.A. Randles, A. Darmenov, M.G. Bosilovich, R. Reichle, K. Wargan, L. Coy, R. Cullather, C. Draper, S. Akella, V. Buchard, A. Conaty, A.M. Da Silva, W. Gu, G.-K. Kim, R. Koster, R. Lucchesi, D. Merkova, J.E. Nielsen, G. Partyka, S. Pawson, W. Putman, M. Rienecker, S.D. Schubert, M. Sienkiewicz, and B. Zhao (2017)."'MERRA-2." Journal of Climate 30: 5419-5454. https://doi.org/10.1175/JCLI-D-16-0758.1.

Golombek, R., M. Greaker, S.A.C. Kittelsen, O. Røgeberg, and F.R. Aune (2011). "Carbon Capture and Storage in the European Power Market.” The Energy Journal 32 (3): 209-237. https://doi.org/10.5547/ISSN0195-6574-EJ-Vol32-No3-8.

Golombek, R., S.A.C. Kittelsen, and I. Haddeland (2012). "Climate Change: Impacts on Electricity Markets in Western Europe.” Climatic Change 113: 357-370. https://doi.org/10.1007/s10584-011-0348-6. 
Golombek, R., K.A. Brekke, and S.A.C. Kittelsen (2013a). "Is Electricity More Important than Natural Gas? Partial Liberalizations of the Western European Energy Markets.” Economic Modelling 35: 99-111. https://doi.org/10.1016/j.econmod.2013.06.023.

Golombek, R., S.A.C. Kittelsen, and K.E. Rosendahl (2013b). "Price and Welfare Effects of Emission Quota Allocation." Energy Economics 36: 568-580. https://doi.org/10.1016/j.eneco.2012.11.006.

Green, R. and A. Yatchew (2012). "Support Schemes for Renewable Energy: An Economic Analysis.” Economics of Energy \& Environmental Policy 1(2): 83-98. https://doi.org/10.5547/2160-5890.1.2.6.

Grubb, M. and D. Newbery (2018). "UK Electricity Market Reform and the Energy Transition: Emerging Lessons." The Energy Journal 39(6): 1-25. https://doi.org/10.5547/01956574.39.6.mgru.

Gugler, K., A. Haxhimusa, and M. Liebensteiner (2018). "Integration of European Electricity Markets: Evidence from Spot Prices.” The Energy Journal 39(SI2): 41-66. https://doi.org/10.5547/01956574.39.SI2.kgug.

Haar, L.N. and L. Haar (2017). “An Option Analysis of the European Union Renewable Energy Support Mechanisms.” Economics of Energy \& Environmental Policy 6(1): 131-147. https://doi.org/10.5547/2160-5890.6.1.lhaa.

Held, A., M. Ragwitz, P. del Río, G. Resch, C. Klessmann, A. Hassel, M. Elkerbout, and J. Rawlins (2019). "Do Almost Mature Renewable Energy Technologies Still Need Dedicated Support Towards 2030?” Economics of Energy \& Environmental Policy 8(2): 81-98. https://doi.org/10.5547/2160-5890.8.2.ahel.

Höglund-Isaksson, L., W. Winiwarter, F. Wagner, Z. Klimont, and M. Amann (2010). "Potentials and costs for mitigation of non-CO2 greenhouse gas emissions in the European Union until 2030. Results." Report to the European Commission, DG Climate Action Contract No. 537 07.030700/2009/545854/SER/C5. International Institute for Applied Systems Analysis (IIASA), Laxenburg, Austria.

IEA (2011). World Energy Outlook 2011. Paris: OECD Publishing.

IEA (2016). Data retrieved February 28, 2019 from https://ec.europa.eu/knowledge4policy/publication/world-energy-model-documentation_en.

IEA.world energy model WEM.WEO_2016_PG_Assumptions_NPSand450_Scenario.xlsb, New Policy Scenario.

IEA (2018). World Energy Outlook 2018. IEA/OECD. Paris, France.

IEA (2019). Global EV Outlook 2019. Paris.

IEA ETSAP (2010). “Hydropower Technology Brief E12.” IEA Energy Technology Network—Energy Technology Systems Analysis Programme.

International Monetary Fund (2018). World Economic Outlook Database, April 2018.

International Monetary Fund (2019). World Economic Outlook Database, April 2019.

IPCC (2019). "Global warming of $1.5^{\circ} \mathrm{C}$. An IPCC Special Report on the impacts of global warming of $1.5^{\circ} \mathrm{C}$ above pre-industrial levels and related global greenhouse gas emission pathways, in the context of strengthening the global response to the threat of climate change, sustainable development, and efforts to eradicate poverty" [V. Masson-Delmotte, P. Zhai, H.O. Pörtner, D. Roberts, J. Skea, P.R. Shukla, A. Pirani, W. Moufouma-Okia, C. Péan, R. Pidcock, S. Connors, J.B. R. Matthews, Y. Chen, X. Zhou, M.I. Gomis, E. Lonnoy, T. Maycock, M. Tignor, T. Waterfield (eds.)]

IRENA (2012). "Solar Photovoltaics.” Renewable Energy Technologies: Cost Analysis Series, Volume 1 Power Sector, Issue 4/5. International Renewable Energy Agency. Abu Dhabi. https://doi.org/10.5402/2012/328237.

IRENA (2019). "Renewable Power Generation Costs in 2018." International Renewable Energy Agency. Abu Dhabi.

Jägemann, C., M. Fürsch, S. Hagspiel, and S. Nagl (2013). "Decarbonizing Europe's Power Sector by 2050-Analyzing the Economic Implications of Alternative Decarbonization Pathways.” Energy Economics 40 (November): 622-636. https:// doi.org/10.1016/j.eneco.2013.08.019.

Keppler, J.H., S. Phan, and Y. Le Pen (2016). "The Impacts of Variable Renewable Production and Market Coupling on the Convergence of French and German Electricity Prices.” The Energy Journal 37(3): 343-359. https://doi. org/10.5547/01956574.37.3.jkep.

Landis, F. and P. Heindl (2019). "Renewable Energy Targets in the Context of the EU ETS: Whom Do They Benefit Exactly?" The Energy Journal 40(6): 129-169. https://doi.org/10.5547/01956574.40.6.flan.

Léautier, T.-O. (2016). "The Visible Hand: Ensuring Optimal Investment in Electric Power Generation.” The Energy Journal 37(2): 89-109. https://doi.org/10.5547/01956574.37.2.tlea.

LIBEMOD (2015). Documentation. http://www.frisch.uio.no/ressurser/LIBEMOD/.

Marcantonini, C. and A.D. Ellerman (2015). "The Implicit Carbon Price of Renewable Energy Incentives in Germany." The Energy Journal 36(4): 205-239. https://doi.org/10.5547/01956574.36.4.cmar.

Mott MacDonald (2010). “UK Electricity Generation Costs, Update 2010.” London: Department of Energy and Climate Change.

Neuhoff, K., S. Wolter, and S. Schwenen (2016). "Power Markets with Renewables: New Perspectives for the European Target Model." The Energy Journal 37(SI2): 23-38. https://doi.org/10.5547/01956574.37.2.kneu. 
Newbery, D.M. (2012). “Contracting for Wind Generation.” Economics of Energy \& Environmental Policy 1(2): 19-36. https://doi.org/10.5547/2160-5890.1.2.2.

Newbery, D.M. (2018). "What future(s) for liberalized electricity markets: efficient, equitable or innovative?" The Energy Journal 39(1): 1-27. https://doi.org/10.5547/01956574.39.1.dnew.

Newbery, D.M., M.G. Pollitt, R.A. Ritz, and W. Strielkowski (2018). "Market design for a high-renewables European electricity system." Renewable and Sustainable Energy Reviews 91: 695-707. https://doi.org/10.1016/j.rser.2018.04.025.

OECD (2010). "Projected Costs of Generating Electricity 2010." Paris: OECD Publishing. https://doi. org/10.1787/9789264084315-en.

OECD (2018). Dataset: Economic Outlook No 103_July 2018_-Long-term baseline projections. Data retrieved on May 22, 2019.

Panos, E. and M. Densing (2020). "The future developments of the electricity prices in view of the implementation of the Paris Agreement: Will the current trends prevail, or a reversal is ahead?" Energy Economics, forthcoming. https://doi. org/10.1016/j.eneco.2019.104476.

Perez-Arriaga, I.J. and C. Batlle (2012). "Impacts of Intermittent Renewables on Electricity System Operation.” Economics of Energy \& Environmental Policy 1(2): 3-17. https://doi.org/10.5547/2160-5890.1.2.1.

Pollitt, M.G. (2019). “The European Single Market in Electricity: An Economic Assessment.” Review of Industrial Organization 55(1): 63-87. https://doi.org/10.1007/s11151-019-09682-w.

Pollitt, M.G. and K.L. Anaya (2016). "Can Current Electricity Markets Cope with High Shares of Renewables? A Comparison of Approaches in Germany, the UK and the State of New York." The Energy Journal 37(SI2): 69-88. https://doi. org/10.5547/01956574.37.SI2.mpol.

PRIMES (2019). Data retrieved November 10, 2019 from https://ec.europa.eu/energy/sites/ener/files/technical_note_on_ the_euco3232_final_14062019.pdf.

Ringel, M. and M. Knodt (2018). “The Governance of the European Energy Union: Efficiency, Effectiveness and Acceptance of the Winter Package 2016." Energy Policy 112: 209-220. https://doi.org/10.1016/j.enpol.2017.09.047.

Sandbag (2019). "Halfway There.” Data retrieved December 15, 2019 from https://sandbag.org.uk/wp-content/uploads/2019/04/Halfway-There-March-2019-Sandbag.pdf.

Schröder, A., F. Kunz, J. Meiss, R. Mendelevitch, and C. von Hirschhausen (2013). "Data documentation. Current Prospective Costs of Electricity Generation until 2050.” Berlin: Deutsches Institut für Wirtschaftsforschung (DIW).

Searchinger, T., R. Heimlich, R.A. Houghton, F. Dong, A. Elobeid, J. Fabiosa, S. Tokgoz, D. Hayes, and T-H. Yu (2008). "Use of U.S. Croplands for Biofuels Increases Greenhouse Gases through Emissions from Land-Use Change.” Science 319: 1238-1241. https://doi.org/10.1126/science.1151861.

Skjærseth, J.B., P.O. Eikeland, L.H. Gulbrandsen, and T. Jevnaker (2016). Linking EU Climate and Energy Policies: Decision-making, Implementation and Reform. Cheltenham: Edward Elgar. https://doi.org/10.4337/9781785361289 .

Transport \& Environment (2019). “Electric surge: Carmakers' electric car plans across Europe 2019-25.” European Federation for Transport and Environment, AISBL. Belgium.

UNFCCC (2019). Data retrieved November 10, 2019 from https://www4.unfccc.int/sites/NDCStaging/Pages/All.aspx.

Wolak, F.A. (2019). "The Role of Efficient Pricing in Enabling a Low-Carbon Electricity Sector." Economics of Energy \& Environmental Policy 8(2): 29-52. https://doi.org/10.5547/2160-5890.8.2.fwol.

World Nuclear Association (2019). Data retrieved November 10, 2019 from https://www.world-nuclear.org.

\section{APPENDIX A: MODELING}

\section{Part I: Trade and investment in electricity}

Electricity can be traded via international transmission lines. Each transmission line is owned by a single agent. Let $m$ and $n$ be two countries, and let $z_{m n}$ be the electricity exported from $m$ to $n$, measured at the node of the importing country $n$. Because there is some loss in transmission $\left(\theta_{m n}\right)$, the quantity $z_{m n} /\left(1-\theta_{m n}\right)$ is exported from country $m$. The transmission line owner transports electricity as long as there is a positive difference between (i) the purchasing price in the import country, $p_{n}$, and (ii) the loss-adjusted purchasing value in the exporting country, $p_{m} /\left(1-\theta_{m n}\right)$, less exogenous costs of transmission, $c_{m n}$. Hence, all arbitrage possibilities are exploited. In each time period $t, t \in T$, the pipeline can be used either for imports to country $n$ from country $m$ or for exports 
from country $n$ to country $m$. In addition, the owner can expand the initial capacity of the pipeline, $K_{m n}^{0}$, through investments, $K^{i n v}$. Hence, the profits of the owner of the pipeline between country $m$ and $n$ are:

$$
\Pi_{m n}=\sum_{t \in T}\left\{\left[p_{n t}-\frac{p_{m t}}{1-\theta_{m n}}-c_{m n}\right] z_{m n t}+\left[p_{m t}-\frac{p_{n t}}{1-\theta_{n m}}-c_{n m}\right] z_{n m t}\right\}-c_{m n}^{i n v} K_{m n}^{i n v}
$$

where $c_{m n}^{i n v}$ is the annualized unit capital cost for expansion of electricity transmission lines. Moreover, the owner faces the following constraints:

$$
z_{m n t}-z_{n m t} \leq \alpha_{t} K_{m n} \perp v_{m n t} \geq 0
$$

where $\alpha_{t}$ is the number of hours in period $t$. According to (8), which is valid for trade between $m$ and $n$ in both directions (two inequalities), net trade in either direction in period $t$ cannot exceed total transmission capacity in this period, $\alpha_{t} K_{m n}$. Momentarily pipeline capacity is the sum of initial capacity $\left(K_{m n}^{0}\right)$ and investments in capacity $\left(K_{m n}^{i n v}\right)$ :

$$
K_{m n}=K_{n m}=K_{m n}^{0}+K_{m n}^{i n v}
$$

where the first equality ensures that the capacity is the same in both directions. The shadow price $v_{m n t}$ can be interpreted as the tariff (in excess of $c_{m n}$ ) that ensures that demand for transport services does not exceed the available capacity.

The first-order conditions of the transmission line owner for trade in either direction in any period are given by:

$$
p_{n t}-\frac{p_{m t}}{1-\theta_{m n}}-c_{m n}-v_{m n t}+v_{n m t} \leq 0 \perp z_{m n t} \geq 0,
$$

whereas the first-order condition for investment in electricity transmission is given by:

$$
\sum_{t \in T} \alpha_{t}\left(v_{m n t}+v_{n m t}\right) \leq c_{m n}^{i n v} \perp K_{m n}^{i n v} \geq 0 .
$$

Inequality (11) takes into account that investment increases capacity in both directions, and also that the increased capacity can be utilized in all periods.

\section{Part II: Capacity market}

In each model country, the national regulator has to avoid a domestic electricity market breakdown triggered by either an unexpected increase in demand or an unexpected decrease in supply. In the case of an unexpected event, the national regulator acquires idle maintained capacity from the domestic power producers (except intermittent producers, run-of-river plants and nuclear plants). Through demand for, and supply of, capacity, a competitive price of reserve capacity, $p_{t}^{K R}$, is determined in each time period.

Supply of reserve capacity from a power plant is determined as part of the problem of maximizing profits subject to a number of constraints. A power producer $l$ can use its maintained capacity, $K_{l}^{P M}$, either to produce electricity or to sell it at the capacity market in period $t, K_{l t}^{P R}$. Hence, in each time period, production of electricity is constrained by the maintained capacity available for production: 


$$
y_{t l} \leq \alpha_{t}\left(K_{l}^{P M}-K_{t l}^{P R}\right) \perp \varepsilon_{t l} \geq 0
$$

where $\alpha_{t}$ is the number of hours in period $t$.

The first-order condition with respect to reserve power capacity sold in each period is:

$$
p_{t}^{K R} \leq \varepsilon_{t l} \alpha_{t} \perp K_{t l}^{P R} \geq 0 .
$$

Hence, for positive reserve power sales in period $t$, the reserve power price in this period, $p_{t}^{K R}$, must equal the shadow value (in period $t$ ) of increasing the power capacity available to produce electricity $\left(\varepsilon_{t l} \alpha_{t}\right)$, that is, for each power producer that is allowed to sell idle capacity, the marginal unit of power capacity should be worth the same either if it is sold as reserve power or used to produce electricity.

In LIBEMOD, the requirement that sufficient idle capacity is available in case there is an unexpected increase in net demand is modeled as follows: in each time period, total idle capacity $\left(\sum_{l} K_{t l}^{P R}\right)$ should exceed a share $(\rho)$ of total maintained capacity $\left(\sum_{l} K_{l}^{P M}\right)$ :

$$
\rho \sum_{l} K_{l}^{P M} \leq \sum_{l} K_{t l}^{P R} \perp p_{t}^{K R} \geq 0
$$

The price of capacity is positive only if the constraint is binding. ${ }^{24}$

\section{APPENDIX B: CALIBRATION}

\section{Part I: Calibration of wind power}

In Section 4.2.1, we defined full-load wind hours as the number of hours with ideal wind conditions (wind speed exceeding, say, $15 \mathrm{~m} / \mathrm{s})^{25}$ that are required to generate the observed annual wind power production. We also introduced $f\left(K^{P M}\right)$, which shows the average number of full-load wind hours per year as a decreasing function of aggregate maintained capacity, $K^{P M}$. We now let $w$ denote wind power and impose that $f\left(K_{w}^{P M}\right)$ is linear:

$$
f\left(K_{w}^{P M}\right)=a_{w}-b_{w} K_{w}^{P M} .
$$

The interpretation of the parameter $a_{w}$ is simply the full-load wind hours per year at the best site (in a country).

From MERRA-2 (Modern-Era Retrospective analysis for Research and Applications, version 2; see Gelaro et al. (2017)), we have access to hourly weather observations, such as wind speed and solar irradiance, for the period 2006-2015 for each of the 30 LIBEMOD countries. The spatial resolution is a latitude-longitude grid of cells of $0.5^{\circ} \times 0.625^{\circ}$. Roughly, each cell is $50 \mathrm{~km} \times 50$ $\mathrm{km}$ in size.

Using detailed information about a Norwegian wind park, we have estimated a wind power curve; for details, see the Appendix in Gaure and Golombek (2019). ${ }^{26}$ Combining this power curve

24. The effect of having no restriction like (14) (i.e., $\rho=0$ ) compared to having $\rho=0.05$ like in the Reference scenario, is a decrease in maintained power capacity of around 5 percent $(62 \mathrm{GW})$. The corresponding decrease in annual cost of maintenance is around 750 million euro.

25. Strictly speaking, above another threshold, say, $25 \mathrm{~m} / \mathrm{s}$, the wind mill must be shut down to avoid damages.

26. We have used information from the Høg-Jæren wind park, located in the southwest of Norway, to estimate the power curve. With this power curve, the full-load wind hours among the top 10 percent onshore wind cells in Germany (2658 hours) 
with information on site-specific hourly wind speeds from MERRA-2, and taking the system electricity loss in wind parks into account, which, according to industry experts, is in the order of 3 percent, we can simulate hourly wind power production in the period 2006-2015. Therefore, we can identify the grid cell with the highest full-load wind hour $\left(a_{w}\right)$ and the cell with the lowest fullload wind hour (henceforth referred to as $d_{w}$ ) in each country, see Table B.1. From the simulations, we also find the parameter $\psi_{t}^{w}$, that is, the share in period $t$ of annual full-load wind hours (in each country).

By using detailed information on a number of Norwegian onshore wind parks, Gaure and Golombek (2019) find that if $1 \mathrm{GW}$ of wind capacity is installed (and maintained) in a grid cell, then roughly 5 percent of the gross land in the grid cell is used for wind parks. ${ }^{27}$ We use this relationship for all grid cells in all countries. Furthermore, in the Reference scenario, we assume that because of land regulation, $1 \mathrm{GW}$ capacity can be installed in each grid cell.

Table B.1: Full-load wind hours at best site and worst site in wind parks by country.

\begin{tabular}{|c|c|c|c|c|c|}
\hline Country & $\begin{array}{c}\text { Full-load wind } \\
\text { hours } \\
\text { at best site }\end{array}$ & $\begin{array}{c}\text { Full-load wind } \\
\text { hours } \\
\text { at worst site }\end{array}$ & Country & $\begin{array}{c}\text { Full-load wind } \\
\text { hours } \\
\text { at best site }\end{array}$ & $\begin{array}{c}\text { Full-load wind } \\
\text { hours } \\
\text { at worst site }\end{array}$ \\
\hline Austria & 1923 & 128 & Latvia & 2933 & 796 \\
\hline Belgium & 2449 & 2034 & Lithuania & 2655 & 780 \\
\hline Bulgaria & 1732 & 243 & Luxembourg & 1758 & 1758 \\
\hline Cyprus & 1122 & 1026 & Malta & 2016 & 2016 \\
\hline Czech Republic & 2125 & 1109 & Netherlands & 3398 & 2206 \\
\hline Denmark & 3544 & 2840 & Norway & 3085 & 464 \\
\hline Estonia & 3176 & 1469 & Poland & 2783 & 1049 \\
\hline Finland & 2097 & 673 & Portugal & 2235 & 552 \\
\hline France & 3130 & 57 & Romania & 1932 & 414 \\
\hline Germany & 3187 & 230 & Slovak Republic & 1734 & 561 \\
\hline Greece & 2421 & 282 & Slovenia & 1154 & 201 \\
\hline Hungary & 1898 & 819 & Spain & 2314 & 572 \\
\hline Iceland & 3951 & 1844 & Sweden & 3022 & 586 \\
\hline Ireland & 3834 & 2779 & Switzerland & 1119 & 126 \\
\hline Italy & 2090 & 52 & United Kingdom & 4122 & 2244 \\
\hline
\end{tabular}

Source: Own calculations based on MERRA-2 data on wind speed and using the estimated power curve for the Norwegian wind park Høg-Jæren. Note that the estimated power curve reflects maintenance work. Furthermore, full-load wind hours have been adjusted for system electricity losses.

By multiplying maximum maintained wind power capacity in each grid cell (1 GW) by the number of (onshore) cells in a country, we find a measure of maximum maintained (onshore) wind power capacity, $\hat{K}_{w}^{P M}$. Hence, actual maintained capacity should be below this number, that is,

$$
K_{w}^{P M} \leq \hat{K}_{w}^{P M} .
$$

is close to the "expected full-load hours for the new wind turbines" in Germany (2788 hours); see Fraunhofer (2019).

27. This share differs slightly by grid cell because the size of cells (measured in km2) differs. Note that the area between the wind turbines in the wind parks is available for public or private activities; the exact nature of these activities (agriculture, forestry, recreation, private hunting, etc.) will depend on local conditions. The area used for wind mills and infrastructure is substantially lower than the gross area, see the Appendix in Gaure and Golombek (2019). 
Inequality (16) reflects land scarcity with respect to wind power production.

Annual production of wind power is $f\left(K_{w}^{P M}\right) K_{w}^{P M}=a_{w} K_{w}^{P M}-b_{w}\left(K_{w}^{P M}\right)^{2}$, where we have used (15). Therefore, marginal productivity of annual production of wind power is given by $a_{w}-2 b_{w} K_{w}^{P M}$. If maintained capacity is equal to $\hat{K}_{w}^{P M}$, then the site with the lowest full-load wind hours is utilized. By construction, the full-load wind hours at this site is $d_{w}$. Hence, $a_{w}-2 b_{w} \hat{K}_{w}^{P M}=d_{w}$, and thus

$$
b_{w}=\frac{a_{w}-d_{w}}{2 \hat{K}_{w}^{P M}},
$$

which is easy to calculate.

In the LIBEMOD model, restriction (16) is included in the Lagrangian of the wind power producer. Let $\kappa$ be the Lagrange parameter associated with restriction (16). Then the term $c^{M}+\lambda$ in the first-order condition for maintained capacity (

\section{Part II: Calibration of solar power}

Calibration of the solar parameters is similar to the calibration of the wind power parameters. Let $s$ denote solar power. In Section 4.2.2, we introduced the function $g\left(K_{s}^{P M}\right)$, which shows how annual generated electricity delivered to the grid per $m^{2}$ of solar park depends on maintained solar power capacity $\left(K_{s}^{P M}\right)$. We now assume that this function is linear:

$$
g\left(K_{s}^{P M}\right)=a_{s}-b_{s} K_{s}^{P M} .
$$

The parameter $a_{s}$ is annual generated electricity delivered to the grid per $m^{2}$ at the best site (i.e., in the best grid cell).

Gaure and Golombek (2019) study optimal design of solar parks: for a given amount of land available for solar power, what is the tilt of solar panels and what is the distance between rows of solar panels that maximize profits? Using data from MERRA-2, including solar irradiance (measured as surface incoming shortwave flux), reflection (albedo), and temperature in the air, they construct a measure for diffuse radiation and also take into account how the efficiency of solar panels depends on the temperature. The collected and derived variables are used to find optimal solar panel tilts and optimal distance between rows of solar panels; both differ by MERRA-2 grid cells. They find that installation of $1 \mathrm{~kW}$ of capacity in a solar park requires approximately $10 \mathrm{~m}^{2}$ of land. Hence, the total amount of land used for solar parks is $\Omega_{s}=10 \frac{\mathrm{m}^{2}}{\mathrm{~kW}} K_{s}^{P M}{ }^{28}$

Once the optimal tilts are identified, Gaure and Golombek (2019) simulate how much electricity is generated annually and delivered to the grid by a capacity of $0.1 \mathrm{~kW}$ of solar power, which requires $1 \mathrm{~m}^{2}$ of land. To this end, they take into account the system electricity loss in solar parks, which, according to industry experts, is in the order of 16 percent. Table B.2 shows the results for the best site $\left(a_{s}\right)$ and the worst site (henceforth referred to as $d_{s}$ ) for each of the 30 LIBEMOD countries.

We now determine the value of $b_{s}$ in (18). To this end, we first calculate the required maintained solar power capacity if all grid cells are developed. This requires an assumption on the share of land available for solar parks. In the Reference scenario, we assume that 1 percent of the land in each grid cell can be used for solar parks. Drawing on the derived relationship between land use and capacity referred to above, $\Omega_{s}=10 \frac{m^{2}}{k W} K_{s}^{P M}$, this implies that $2.5 \mathrm{GW}$ of solar capacity can be installed in each grid cell. ${ }^{29}$ By multiplying maximum maintained solar power capacity in each

28. Because the optimal tilt differs by grid cell, the amount of land necessary to install $1 \mathrm{~kW}$ of solar capacity differs slightly by grid cell.

29. Note that the entire area will be covered by solar panels; there is no space for other activities. 
Table B.2: Solar power output in solar parks, $\mathrm{kWh} / \mathrm{m}^{2} / \mathrm{year}$.

\begin{tabular}{|c|c|c|c|c|c|}
\hline Country & $\begin{array}{l}\text { Best site } \\
\mathrm{kWh} / \mathrm{m}^{2} / \mathrm{yr}\end{array}$ & $\begin{array}{l}\text { Worst site } \\
\mathrm{kWh} / \mathrm{m}^{2} / \mathrm{yr}\end{array}$ & Country & $\begin{array}{l}\text { Best site } \\
\mathrm{kWh} / \mathrm{m}^{2} / \mathrm{yr}\end{array}$ & $\begin{array}{l}\text { Worst site } \\
\mathrm{kWh} / \mathrm{m}^{2} / \mathrm{yr}\end{array}$ \\
\hline Austria & 154 & 128 & Latvia & 112 & 104 \\
\hline Belgium & 121 & 119 & Lithuania & 114 & 106 \\
\hline Bulgaria & 157 & 144 & Luxembourg & 125 & 125 \\
\hline Cyprus & 182 & 181 & Malta & 174 & 174 \\
\hline Czech Republic & 133 & 122 & Netherlands & 121 & 115 \\
\hline Denmark & 114 & 109 & Norway & 105 & 31 \\
\hline Estonia & 109 & 102 & Poland & 128 & 113 \\
\hline Finland & 104 & 52 & Portugal & 173 & 155 \\
\hline France & 164 & 120 & Romania & 146 & 131 \\
\hline Germany & 136 & 114 & Slovak Republic & 135 & 125 \\
\hline Greece & 182 & 151 & Slovenia & 142 & 134 \\
\hline Hungary & 139 & 131 & Spain & 182 & 139 \\
\hline Iceland & 92 & 66 & Sweden & 113 & 77 \\
\hline Ireland & 115 & 97 & Switzerland & 165 & 131 \\
\hline Italy & 170 & 134 & United Kingdom & 124 & 87 \\
\hline
\end{tabular}

Source: Own calculations based on MERRA-2 data. Key assumptions: optimal fixed tilt of cells, 18 percent efficiency, and correction for 16 percent system electricity losses.

grid cell $(2.5 \mathrm{GW})$ by the number of grid cells in a country, we find the maximum maintained solar power capacity, which is henceforth referred to as $\hat{K}_{s}^{P M}$. Of course, actual capacity should be lower than this number:

$$
K_{s}^{P M} \leq \hat{K}_{s}^{P M} .
$$

Because $g\left(K_{s}^{P M}\right) K_{s}^{P M}=a_{s} K_{s}^{P M}-b_{s}\left(K_{s}^{P M}\right)^{2}$ shows annual solar power production per $m^{2}$, marginal productivity of annual solar production per $m^{2}$ is $a_{s}-2 b_{s} K_{s}^{P M}$. If maintained solar power capacity is $\hat{K}_{s}^{P M}$, then the site with the lowest output per $m^{2}\left(d_{s}\right)$ has been developed and per construction $a_{s}-2 b_{s} \hat{K}_{s}^{P M}=d_{s}$. Solving this equation with respect to $b_{s}$, we find a relationship similar to (17).

\section{Part III: Calibration of the demand block}

In LIBEMOD, end-user demand is derived from a nested CES utility function with five levels. At the top-nest level, there are substitution possibilities between energy-related goods and other forms of consumption. At the second level, consumers face a trade-off between consumption based on the different energy sources. Each of these is a nest describing complementarity between the actual energy source and consumption goods that use this energy source (e.g., electricity and light bulbs). Finally, the fourth and fifth levels are specific to electricity in defining the substitution possibilities between the summer and winter seasons (fourth level) and time periods over the 24hour cycle (fifth level).

The CES function contains three types of parameters: endowment, share, and substitution. Briefly, the parameters are determined as follows. First, we calibrate income elasticities as the non-price changes in consumption relative to changes in GDP, assuming an annual global energy efficiency rate of 1.6 percent. This rate is taken from the Current Policies Scenario of World Energy Outlook 2011 (IEA 2011). Next, given the calibrated income elasticities and demand observations, 
the endowment and share parameters are determined. Based on a literature review, we then select direct and cross-price elasticities (henceforth referred to as target value elasticities) for all energy goods. These are used to determine the distribution parameters by minimizing the mean squared error, summed over all goods, between each target value elasticity and the corresponding calibrated elasticity; see Aune et al. (2008), Sections 2.4 and 2.7 for details. Note that the calibrated parameters differ between end users in the same country and between the same group of end users in different countries.

The model is calibrated to 2009 data. For a detailed description of the calibration strategy, see Aune et al. (2008).

\section{Part IV: Transforming the GHG target to a $\mathrm{CO}_{2}$ target}

While the EU emissions target is set in terms of GHG gases, the LIBEMOD model covers $\mathrm{CO}_{2}$ only. Therefore, we have to transform the GHG target to a $\mathrm{CO}_{2}$ target. Our transformation strategy is as follows. We use EEA (2013) to find GHG emissions for EU-27 in 1990. The emission target for EU-27 in 2030 is set to 40 percent below this emission level. Furthermore, because Iceland, Norway, and Switzerland have each committed through the Paris Agreement to an emissions reduction of at least 40 percent, see UNFCCC (2019), we assume that these countries will reduce their GHG emissions by 40 percent by 2030 .

Based on Höglund-Isaksson et al. (2010), who provide projections for non- $\mathrm{CO}_{2}$ emissions for the ETS and non-ETS sectors, we find ETS and non-ETS $\mathrm{CO}_{2}$ targets. Furthermore, we take into account that LIBEMOD cannot distinguish between manufacturing firms that belong to the ETS sector (large carbon-intensive units) and manufacturing firms not covered by the ETS sector. When setting the $\mathrm{CO}_{2}$ target for LIBEMOD, we also take into consideration that in the transport sector there is likely to be considerable substitution to other fuels toward 2030. This is not captured by the LIBEMOD model: in the LIBEMOD transport sector, the CES demand structure allows little room for substitution because of the initial share of oil being close to 100 percent.

We believe that there are two main potential errors in transforming the GHG target to a $\mathrm{CO}_{2}$ target. First, we have used the baseline scenario in Höglund-Isaksson et al. (2010), which is consistent with a low carbon price, as we find in our paper. With higher carbon prices, Höglund-Isaksson et al. (2010) predict larger reductions in non- $\mathrm{CO}_{2}$ emissions, which would lower our estimate of the required emissions reduction for $\mathrm{CO}_{2}$. Second, we have assumed a technology shift in the transport sector that will reduce emissions by $250 \mathrm{Mt} \mathrm{CO}_{2}$ by 2030. This estimate builds on the Sustainable Development Scenario in World Energy Outlook 2018 (IEA (2018), p. 550). Whereas PRIMES (2019) and Global EV Outlook (IEA, 2019) indicate that the assumed emissions reduction of $250 \mathrm{Mt}$ $\mathrm{CO}_{2}$ by 2030 is a good estimate, recent developments in EV and ambitious targets for electrification of the car fleet in several European countries (see, e.g., Transport \& Environment (2019)) suggest that there is a high probability that we have underestimated the emissions reduction. If so, this factor will also lower our estimate of the required emissions reduction for $\mathrm{CO}_{2}$.

\section{APPENDIX C: ADDITIONAL RESULTS UNDER CLIMATE EFFICIENCY}

\section{Part I: Welfare by country}

In Section 3, we referred to the process of obtaining an agreement over the EU 2030 climate and energy policy package. Here, we divided countries into three (bargaining) groups; those not pleased with the EU 2020 package, for example, Poland; those with a mixed experience with the EU 2020 package, for example, the Netherlands, and those that mainly had a positive experience 
with the EU 2020 package, for example, Germany. While Germany wanted more ambitious targets, which in the end was agreed upon, neither the Netherlands nor Poland wanted any energy policy targets. Therefore, for these three countries it is interesting to compare welfare in the Climate Efficiency scenario with welfare in the Reference scenario. As seen from Table C.1, all three countries have the highest welfare in the Climate Efficiency scenario, that is, the scenario without energy targets. Note that for all three countries, government net income is lower in the Climate Efficiency scenario than in the Reference scenario. This is in particular the case for Poland.

Table C.1: Welfare components in the Climate Efficiency scenario relative to Reference scenario. EU-30 in 2030 (1000 million €2009)

\begin{tabular}{lcccc}
\hline & EU-30 & Poland & The Netherlands & Germany \\
\hline Producer surplus, electricity & 38.7 & 0.4 & 0.2 & 1.2 \\
Producer surplus, other energy carriers & 6.8 & 0.4 & 1.2 & 0.2 \\
Consumer surplus & 595.5 & 114.0 & 32.0 & 31.0 \\
Trader surplus & 0.3 & 0.2 & 0.0 & 0.0 \\
Government net income & -529.8 & -108.8 & -27.4 & -30.0 \\
Sum & $\mathbf{1 1 1 . 5}$ & $\mathbf{6 . 2}$ & $\mathbf{6 . 0}$ & $\mathbf{2 . 4}$ \\
\hline
\end{tabular}

Figure C.1 provides more information on the Reference and Climate Efficiency scenarios. Here, we measure imports of electricity, natural gas, and coal relative to the sum of end-user consumption of these three energy goods in the Reference scenario. A bar above the horizontal axis reflects imports, whereas a bar below the horizontal axis shows exports.

As seen from Figure C.1, each of the three countries imports more natural gas in the Climate Efficiency scenario than in the Reference scenario, whereas the opposite is the case for electricity. In the Climate Efficiency scenario, there is increased imports of natural gas from Russia, reflecting that the producer price of natural gas is higher in the Climate Efficiency scenario than in the Reference scenario. The reason is simply that there is no end-user tax in the Climate Efficiency scenario; this tax decreases producer prices. The increased imports of natural gas in the Climate Efficiency scenario are mainly used for gas power production, either by retrofitting existing gas power stations or by investing in new CCS gas power. This effect is so strong that the Netherlands becomes an importer of natural gas and an exporter of electricity in the Climate Efficiency scenario.

\section{Part II: Additional policy instruments}

In Section 6.1.2, we studied the impacts of alternative energy targets when the emissions targets were fixed. We now conduct a similar analysis under the Climate Efficiency scenario. We keep the assumption of a common emissions target that leads to the same GHG emissions reduction as in the Reference equilibrium, and study how the common $\mathrm{CO}_{2}$ price has to be adjusted if the EU imposes either a common renewable subsidy to stimulate renewable electricity or imposes a common end-user tax on energy to improve energy efficiency.

Figure C. 2 shows the case when the EU offers a subsidy to all producers of renewable electricity. Here, a zero subsidy corresponds to the equilibrium in the Climate Efficiency scenario. As seen from the figure, as the renewable subsidy is increased, the $\mathrm{CO}_{2}$ price drops. A higher renewable subsidy stimulates supply of renewable electricity, which reduces the producer price of electricity. Hence, fossil fuel-based electricity production, which is mainly CCS gas power production, drops. This tends to lower emissions from the electricity generation sector. Because total emissions per 
Figure C.1: Imports of electricity, coal and natural gas as a percentage of total end-user consumption of these three energy goods in the Reference scenario. EU-30, Poland, the Netherlands, and Germany.

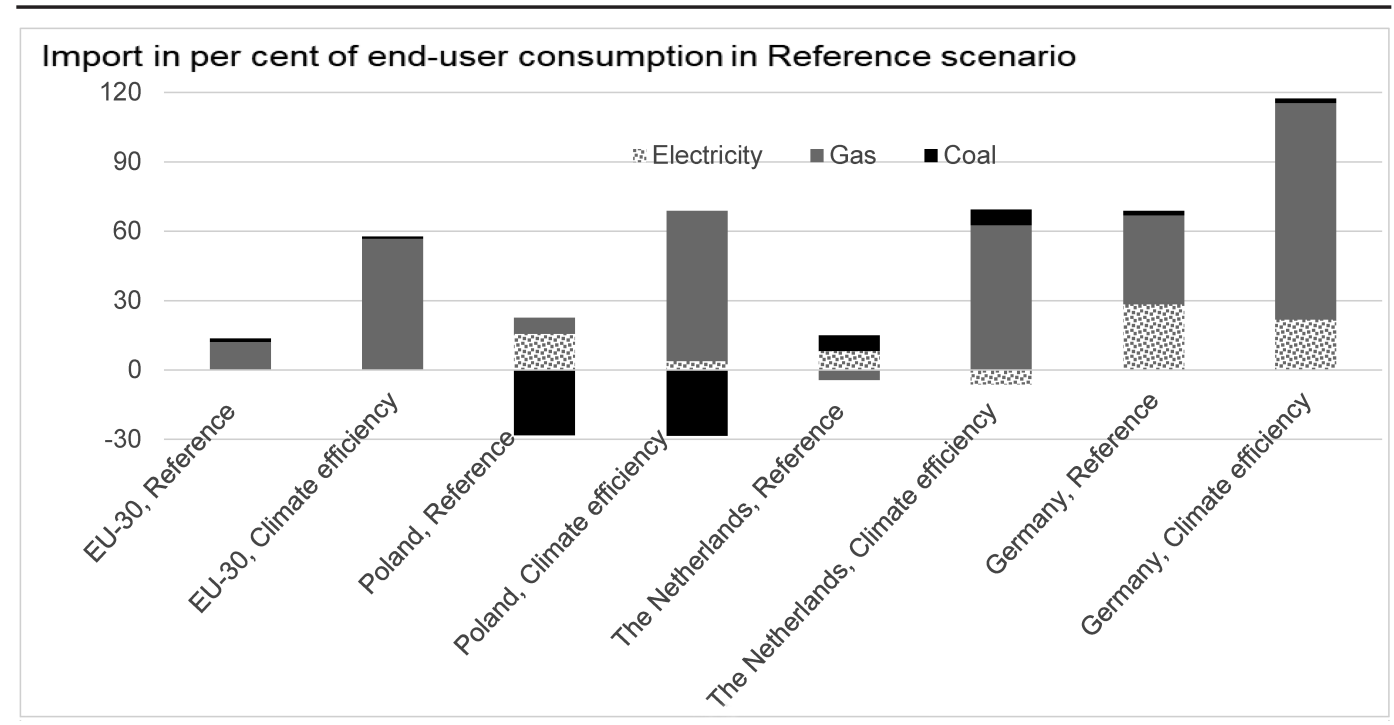

Figure C.2: Equilibrium relationship between renewable subsidy and $\mathrm{CO}_{2}$ price when total emissions are fixed at 50 percent below the 1990 level.

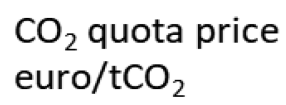

330

320

310

300

290

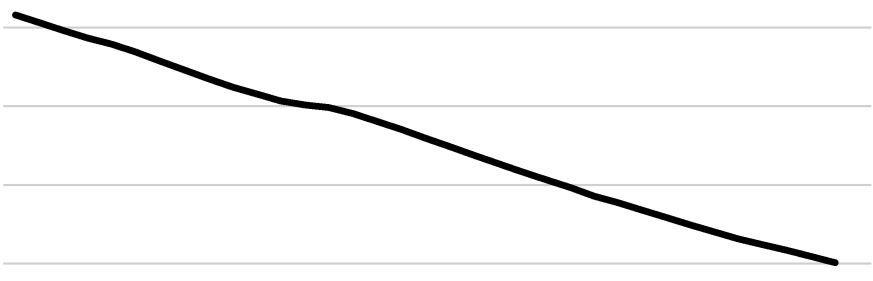

280

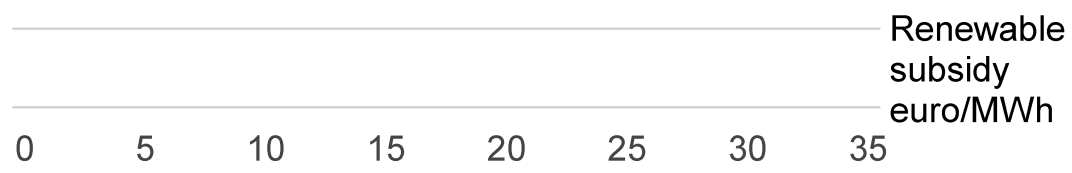

assumption are constant, emissions in the end-user sectors should increase. This requires a reduction in the common $\mathrm{CO}_{2}$ price; if not, end-user emissions would be too low.

If, alternatively, the EU imposes a common energy tax on all end users, demand for electricity drops and hence total production of electricity, as well as the producer price of electricity, decreases. As the energy tax is increased up to $€ 600 /$ toe, fossil fuel-based electricity production, which is mainly CCS gas power production, decreases. Hence, emissions in the electricity generation sector decrease. Because total emissions per assumption are constant, emissions in the end-user sectors should increase. This is accomplished by decreasing the common $\mathrm{CO}_{2}$ price (Figure C.3). 
Figure C.3: Equilibrium relationship between end-user tax on energy and $\mathrm{CO}_{2}$ price when total emissions are fixed at 50 percent below the 1990 level.

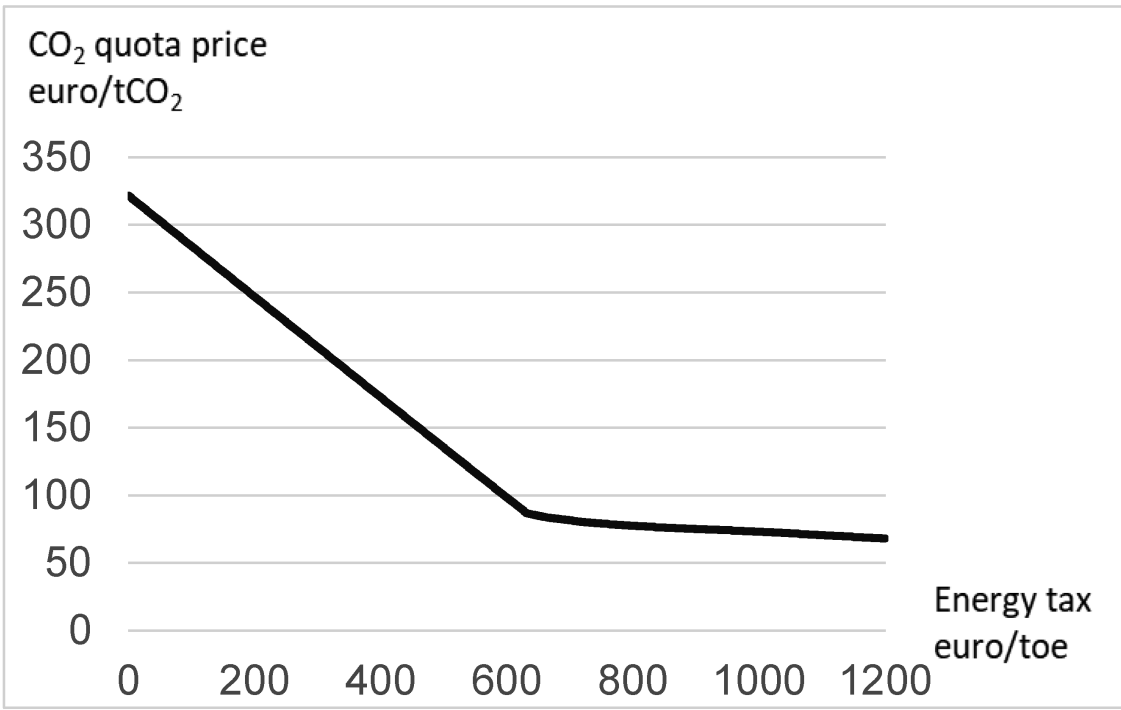

When the energy tax is increased from $€ 600 /$ toe to $€ 1200 /$ toe, CCS gas power production continues to fall, but now it becomes profitable to invest in conventional gas power stations. Because gas power production generates substantial emissions, in the electricity generation sector emissions increase, but not by very much. To ensure that total emissions are constant, emissions among the end users have to drop slightly. This is accomplished by lowering the common $\mathrm{CO}_{2}$ price moderately. To sum up, a higher energy tax leads to a lower $\mathrm{CO}_{2}$ price, and the effect is strongest when the tax is below $€ 600 /$ toe (Figure C.3). 